\title{
Creating Shared Value and Strategic Corporate Social Responsibility through Outsourcing within Supply Chain Management
}

\author{
Atour Taghipour ${ }^{1}\left(\mathbb{D}\right.$, Moein Khazaei ${ }^{2}$, Adel Azar ${ }^{2}{ }^{*}$, Ali Rajabzadeh Ghatari ${ }^{2}$, Mostafa Hajiaghaei-Keshteli ${ }^{3}$ (D) \\ and Mohammad Ramezani ${ }^{2}$ (D) \\ 1 Faculty of International Business, Normandy University, 76600 Le Havre, France; \\ atour.taghipour@univ-lehavre.fr \\ 2 Faculty of Industrial Management, Tarbiat Modares University, Tehran 14115, Iran; \\ moein.khazaei@modares.ac.ir (M.K.); alirajabzadeh@modares.ac.ir (A.R.G.); \\ mohamad.ramezani@modares.ac.ir (M.R.) \\ 3 Escuela de Ingeniería y Ciencias, Tecnologico de Monterrey, Puebla 72220, Mexico; mostafahaji@tec.mx \\ * Correspondence: azara@modares.ac.ir; Tel.: +98-21-22284148
}

\section{check for} updates

Citation: Taghipour, A.; Khazaei, M.; Azar, A.; Rajabzadeh Ghatari, A.; Hajiaghaei-Keshteli, M.; Ramezani, M. Creating Shared Value and Strategic Corporate Social Responsibility through Outsourcing within Supply Chain Management. Sustainability 2022, 14, 1940 https://doi.org/10.3390/su14041940 Academic Editor: Francisco Guijarro

Received: 20 December 2021

Accepted: 3 February 2022

Published: 9 February 2022

Publisher's Note: MDPI stays neutral with regard to jurisdictional claims in published maps and institutional affiliations.

Copyright: () 2022 by the authors Licensee MDPI, Basel, Switzerland. This article is an open access article distributed under the terms and conditions of the Creative Commons Attribution (CC BY) license (https:// creativecommons.org/licenses/by/ $4.0 /)$.

\begin{abstract}
One way to develop local clusters is to strengthen those clusters by using outsourcing to conduct strategic social responsibility, or in other words, to create shared value, which is a win-win strategy for the buyer, supplier, and society and the best and most viable alternative to traditional corporate social responsibilities. In the leading research, a model for decision-making within the supply chain has been developed for purchasing based on shared value creation, long-term relationship management, and purchasing strategies. The research consists of two strategic mathematical models, using goal programming, and then is solved by a meta-heuristic algorithm. Potential outsourcing companies are assessed and then clustered according to their geographic locations in the decisionmaking process. One (or several) cluster(s) was selected among clusters based on knowledge and relationship criteria. Besides, in the primary mathematical model, the orders in different periods and the selection of suppliers are determined. In this model, in addition to optimizing the cost, the dispersion of purchases from suppliers is maximized to increase relationships and strengthen all members of the cluster. Maximizing the distribution by converting a secondary objective function to goal-programming variables transforms the multi-objective model into a single-objective model. In addition to economic benefits for buyers and suppliers, this purchasing plan concentrates on strengthening the local industrial cluster, fostering employment and ease of recruitment for human resources, accessing more infrastructures and technical support facilities, developing an education system in the region, and assisting knowledge-based enterprises with development.
\end{abstract}

Keywords: creating shared value; strategic social responsibility; supply chain management; outsourcing; meta-heuristic

\section{Introduction}

In the past, suppliers, manufacturers, and distributors worked separately and distributed in their way [1]. Producers looked to suppliers as a rival [2], and they feared the benefits of suppliers because of their ties to other producers [3]. In this regard, the supply chain and issues such as shopping cart selection can play a key role in creating a competitive advantage for companies [4]. The emergence of new and healthier perspectives, such as corporate social responsibility (CSR), sustainability, and shared value creation, or strategic types of CSR [5,6], as well as resilience, has been of great interest to researchers in the supply chain and purchasing issues in recent years $[7,8]$.

Today, companies have found that their purchasing sector can be increasingly productive [9] in improving their efficiency and effectiveness [10,11]. Companies need to work 
with different suppliers [12] to continue their activities strategically. In this regard, every strategic purchase requires a strategic purchasing plan [13] for the intended product, which means a strategic relationship with the suppliers [14]. It is evident that to accomplish this, it is necessary to establish strategic relationships with well-qualified and selected suppliers [15] to achieve competitive advantages alongside strategic partnerships [15].

More attention has been paid to cost issues and product quality [16]. If organizations concentrate on supplier selection and purchasing strategies based on cost minimization [17], they will lose long-standing opportunities [18] for effective communication with society, and they may lose their competitive advantages $[9,19]$. In general, it can be said that adopting purchasing strategies that pursue other aims along with cost reductions can have an active role in long-term [20] and multi-aspect communication with suppliers [21] and especially provide a new opportunity to address social issues to create novel competitive advantages $[19,22]$.

In recent years, impact investors' attention to social and environmental issues has been very important. As Figure 1 shows, these investments have been made in various sectors. On the other hand, this investment can develop local clusters through fair sourcing. According to the Global Impact Investing Network (GIIN), the effects of such sourcing are specified in the highlighted categories of Figure 1 and are extremely in line with creating shared value [23].

\section{Share of respondents}

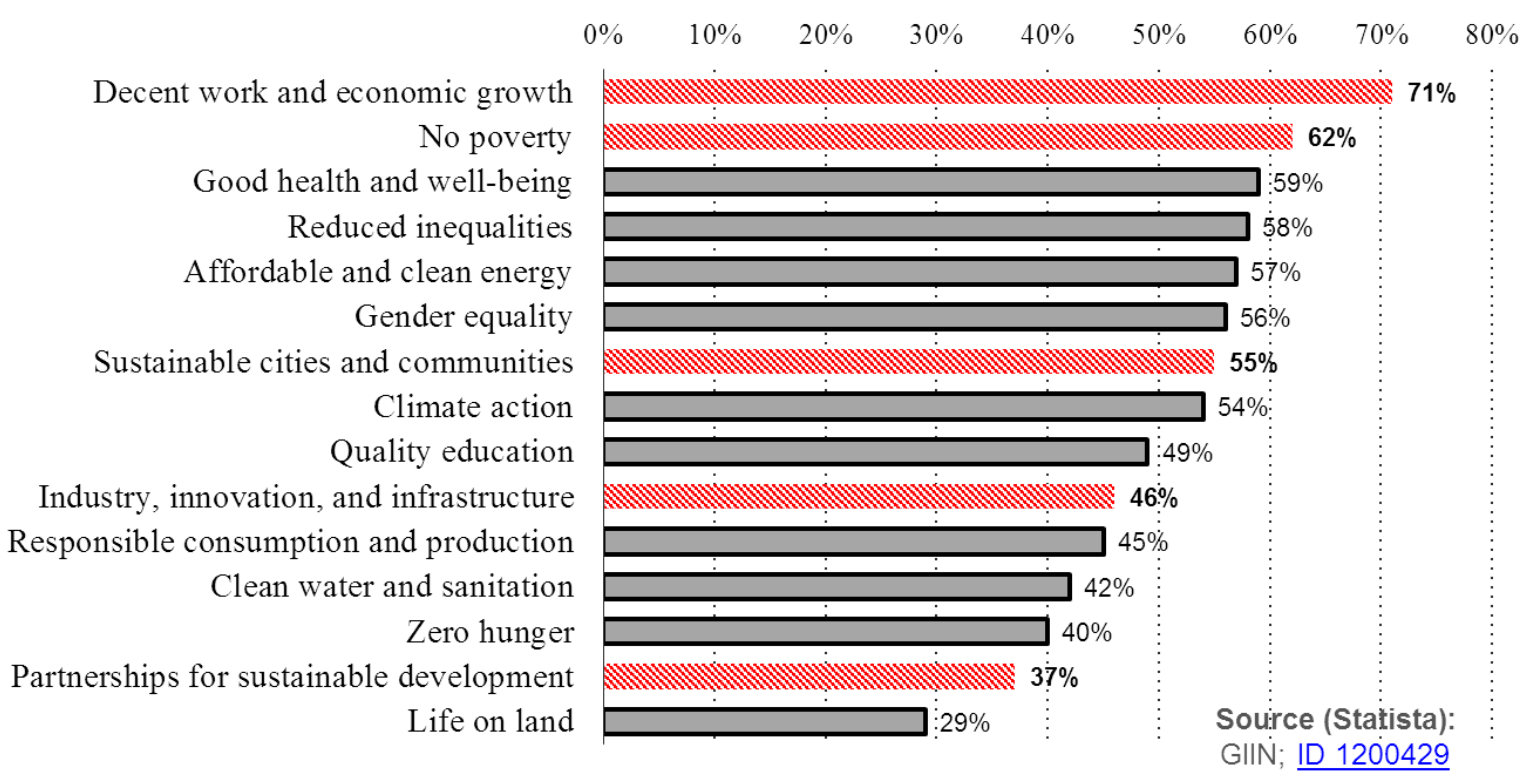

Figure 1. Sustainable development goal (SDG) themes targeted by impact investors worldwide in 2020, according to GIIN (accessed on 10 December 2021).

Creating shared value requires an advanced method [24] to address social issues [23] while simultaneously creating a competitive economic advantage [25]. Shared value is a concept in which companies can achieve this superior competitive position by either developing services and products [26] for unserved needs or through local investments [27] and cluster development [27-29] or developments in the supply chain [30,31].

This competitive argument is inherently accompanied by the objective of solving societal challenges [32] with business means to regain legitimacy for business [27,33]. A shared value perspective also concentrates on improving growing techniques and consolidating the local cluster [29,34,35] of supporting suppliers and other network members [36].

Various companies present themselves as being committed to promoting the local economy [37] and social development and the welfare of the community [38] residents, utilizing financial donations, enhancing local employment [39], supporting local purchasing, and financing for local community development and public welfare projects [40]. All 
companies depend on external parties, such as suppliers, service firms, and infrastructure providers [24].

In this regard, a firm's productivity and ability to create shared value may be strongly affected by clusters [26,41], which indicate a geographic concentration $[41,42]$ of companies with related businesses and different institutions in a given field [24]. Contributing to the development of such clusters is an excellent opportunity for creating shared value [43], but it may require substantial innovation activity [36]. Product innovation or business model innovation may be insufficient since clusters' development calls for management innovation and organization innovation [24].

Not only does Iran suffer from unfair distribution and wealth, but there is no strong will at the level of the Government and Islamic Parliament to deal with such a crisis in the current capitalistic system [44,45]. In this kind of atmosphere, the potential ecosystem is appropriately provided to pay attention to strategic forms of CSR [44] and invest to solve social challenges. Among the challenges outlined in Figure 1 are poverty, unemployment problems, and sustainable societies. Figure 2 shows the extent to which the provinces of Iran are involved in poverty and unemployment. This research aims to create a model to address these challenges, although it should not be overlooked that the existing infrastructure in these geographical areas is crucial. Some provinces (such as Sistan and Baluchestan) suffer from extreme poverty and unemployment, but on the other hand, there is no infrastructure to outsource products to companies in this province.

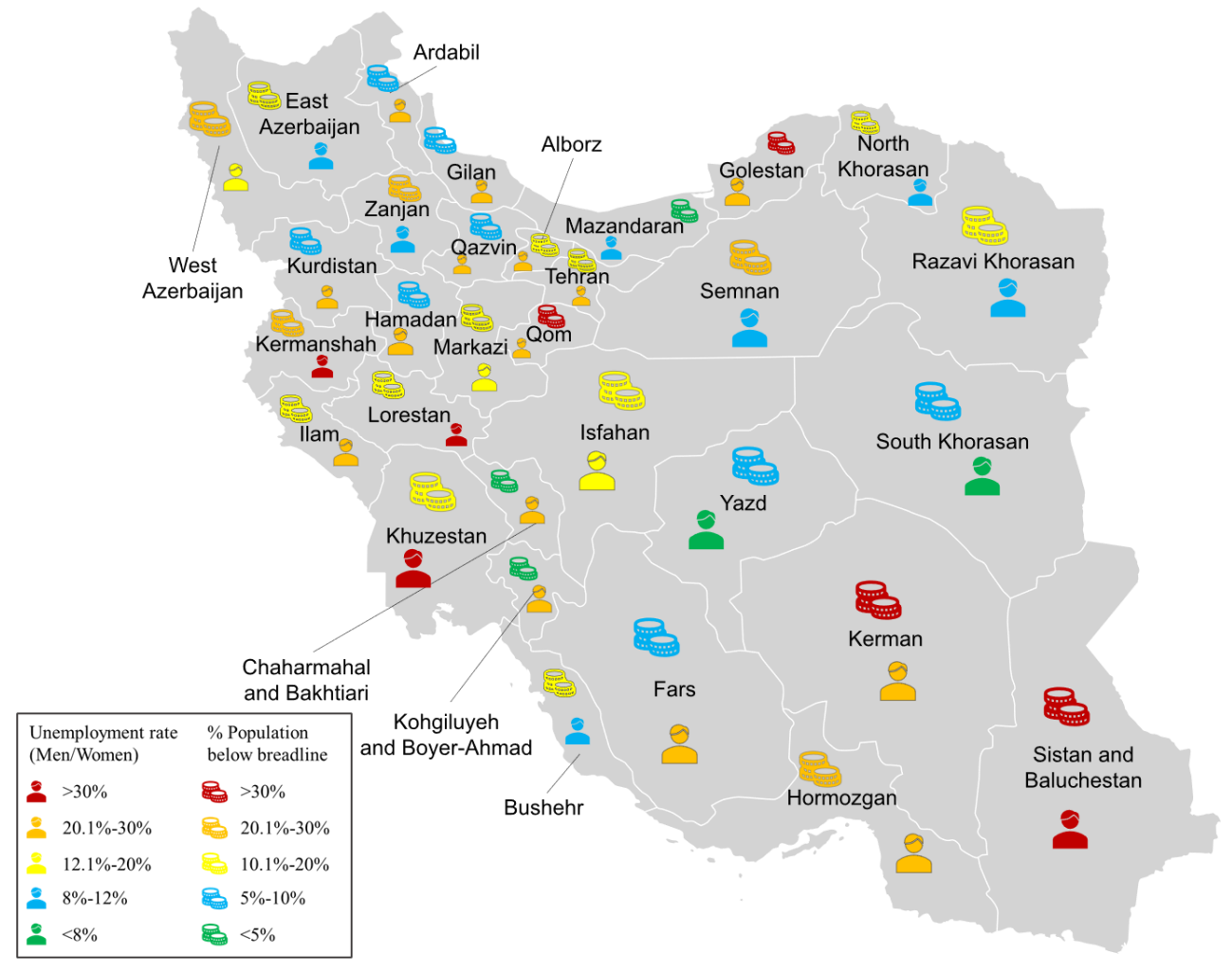

Figure 2. Poverty and the unemployment rate of Iran's provinces, according to the Statistical Centre of Iran (2018) and The Research Center of Islamic Legislative Assembly (2020).

Given that many companies in Iran have resorted to social responsibility fraud, large holdings and leading companies are looking for a way to convince public opinion of their legitimacy, and the main motivation of this research is to meet such a need. When a company in Iran can solve a social challenge, government and public attention are drawn to that company, and new opportunities are provided. For example, Danette Company in Tehran Province has taken positive measures to improve the life of the workforce and make its processes healthier. In this regard, the National Standard Organization of Iran has 
allowed Danette to surpass its competitors. On the other hand, companies that went against creating common value have been marginalized by both social media and the government. The main target of this research model is the strengthening of potential clusters with available infrastructures for outsourcing to diminish social challenges. Moreover, this research aims to design a strategic model for selecting suppliers in several stages. The model under study should be designed to develop local industrial clusters. We also need to look at the company's internal stakeholders and the relationship among suppliers and the buyer so that the interests of the various stakeholders are appropriately met.

The rest of the paper is organized as follows. Section 2 reviews the research background and illustrates the previous efforts. In Section 3, the mathematical models are presented, and the model's materials are clarified. Section 4 shows the results of a real case by the methodology developed, which was used in the case of the pharmaceutical industry in Iran. Finally, in Section 5, we conclude the paper with a summary and discuss future work.

\section{Literature Review}

The historical evolution of suppliers' developments has been examined, and we must look at the supplier-oriented views affected by the strategies. First, Spekman [21], professor of marketing at the University of Southern California, criticized the non-strategic look at the supplier's choice in his research.

Based on our strategic views and our focus on social issues in this study, the view of creating shared value became the basis of this research. In previous studies, little effort had been made in this area; therefore, the closest efforts have been assumed in this section, which collectively forms the anatomy of the developed conceptual model of the present study. Before reviewing articles related to these topics, we have briefly reviewed the published articles regarding supplier selection.

For this purpose, we have extracted the summary of all related journal articles published from 2010 to 2020 from the Scopus database. This was carried out with the "Supplier Selection" keyword, and we did not include conference papers and book chapters in the review. A total of 2877 abstracts were extracted. We then put the abstracts of the articles related to each year in a separate file and analyzed the resulting files with Voyant Tools software using the Mandala tool. As illustrated in Figure 3, Mandala output is a conceptual visualization that shows the relationships between terms and documents. Each search term (or magnet) pulls documents toward it based on the term's relative frequency in the corpus $[46,47]$.

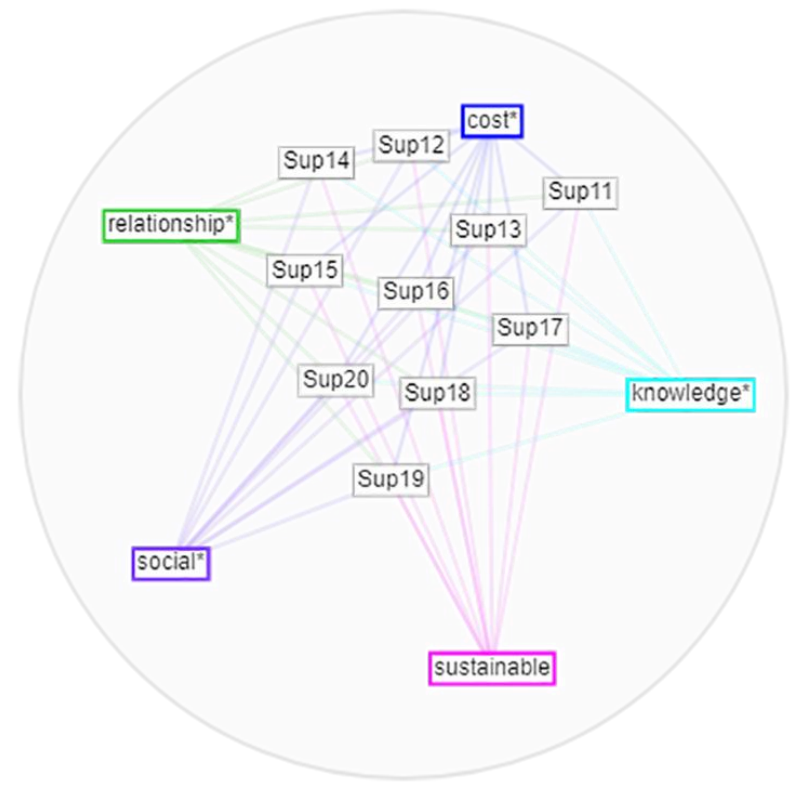

Figure 3. Mandala analysis on ten years of recent corpus extracted on the subject of supplier selection. 
The Mandala analyses were carried out with five keywords related to this research: cost (optimization of purchase and order cost), relationship (long-term relationship with the supplier), knowledge (supplier selection based on knowledge criteria and knowledge sharing), sustainability, and social (attention to creating shared value and sustainability of supplier network). Mandala's output showed us that research over the past three years was closer to sustainability and social issues; therefore, this analysis demonstrates the need to move toward the social direction. Accordingly, the research from the 4 years of 2011 to 2014 is closer to cost issues. In the following, we will examine the research close to the present article's general areas: creating shared value and strategic corporate social responsibility through the supply chain.

\section{Corporate Social Responsibility (CSR) and Creating Shared Value (CSV)}

The research performed by Zhang et al. [48] aimed to clarify the impact of supplier development experiences on supply chain social responsibility. The investigation used a qualitative case study approach and empirically explored how to develop supplier CSR abilities in a pharmaceutical supply chain. Xu et al. [49] focused on a supplier selection problem regarding CSR. Notably, seven criteria and their corresponding significance for supplier selection were analyzed. Meanwhile, some related sub-criteria were covered as well. Based on the current literature review and managerial interviews acquired from leaders in the southern area of India, these problems were compared and ranked. Finally, the research concluded with a presentation of the rankings and priorities of the proposed seven criteria. Given the acquired consequences and recommendations, it would be beneficial to set up a useful approach for selecting the exceptional supplier based on CSR.

Given the vagueness of experts' opinions and the complicated interrelationships amongst evaluation criteria, Chen et al. [50] proposed and illustrated a hybrid model that combines total interpretive structural modeling (TISM) and fuzzy analytic network process (FANP) to decide the most splendid supplier from a social responsibility perspective. Yadlapalli et al. [51] addressed how social responsibility can be carried out at the manufacturing facilities in global supply chains. The research conceptualized supplier selection and supplier development as the governance mechanisms of social responsibility. The consequences disclose that supplier selection and supplier-development governance mechanisms positively impact a firm's social and environmental performance.

Govindan et al. [52] proposed a model to select the best supplier based on their corporate social responsibility (CSR) practices and to discover the key actors (shareholder, governments, customers, and community) whose viewpoint is vital. They utilized a hybrid multi-criteria decision-making (MCDM) approach; however, the supplier selection portion depends on a transparent decision-making process considering multiple criteria. The model is presented in three phases: fuzzy Delphi, DEMATEL-ANP, and PROMETHEE.

The purpose of Mani et al. [53] was to explore the social problems pertinent to suppliers and to perceive measures and dimensions relevant to social sustainability in rising economies. Further, it explored the benefits suppliers, and buyers achieve by efficiently managing such social issues. The findings exposed that 18 validated supplier social sustainability measures were underlying five social dimensions: labor rights, safety and health, societal responsibility, diversity, and product responsibility. Girdwichai and Sriviboon [54] signified the relationship between the social sustainability of suppliers and their impact on the supplier's economic and social performance. They also focused on the supplier company's popularity and its role between sustainability and performance.

Yaghin and Sarlak [55] aimed to suggest an integrated supplier selection, order allocation, transportation planning model, and investment planning for corporate social responsibility (CSR) over a given multi-period horizon under uncertainty. Furthermore, the total market demand viewed a customer's behavior to pay extra cash for CSR attributes. Moreover, the authors observed that the social investment of the buyer, to stimulate market demand, can affect the total profit (TP) and involve the total contribution of suppliers in social responsibility. 
The exploratory study performed through Fontana and Egels-Zandén [56] of 30 exportoriented and first-tier apparel suppliers in Bangladesh, a developing country, revealed the need to spread CSR homogeneously amongst suppliers and reconceptualize the meaning of CSR in developing countries, encouraging more scrutiny toward horizontal dynamics. The aim of Fontoura and Coelho [57] was to perceive the influence of the supply chain leadership (SCL) and followership (SCF) on corporate social responsibility (CSR), considering the moderator role of the supply chain leadership dependency (SCLD). Additionally, they considered the mediating effects of information sharing (IS), shared value (SV), and purchasing social responsibility (PSR), since these variables might also assist in understanding the chain of effects that leads to a sustainable supply chain. They implied that PSR and SV have a powerful influence on CSR.

Wen et al. [58] performed a bibliometric evaluation primarily based on 4687 papers on supplier management from 1997 to 2017. The outcomes demonstrated that the supplier management field has made breakthroughs in both breadth and depth. Representative themes, especially "sustainable supply chain," "corporate social responsibility," and "knowledge management," have gently penetrated the area of supplier management. Research relevant to "supplier selection" and "supplier relations" have usually been of the highest strategic importance.

Hoque and Rana [59] made two contributions in their review article. First, it synthesized buyer-supplier relationship (BSR) typologies and grouped them into nine main dimensions, namely transaction orientation, relation orientation, operational excellence, partnership form, governance pattern, information exchange mode, cooperative mindset, collaborative attitude, and strategic orientation, and demonstrates a relationship amongst the BSR dimensions, supplier's working environment, and organizational performance. Second, their findings exhibited that the working environment is essential in cross-border sourcing and supply management; however, it has been overlooked in the BSR literature from nearly every disciplinary perspective. They concluded by employing six research agendas: governance and shared value/strategic CSR, capability improvement and value appropriation, intervention and productiveness enhancement, knowledge augmentation, institutional impact, industry condition, and sustainable practices. They talked about these research agendas and illustrated a pathway to improve research on the intersection of the three issues in BSR in a cross-border context.

In previous research, there have been many discussions about "why" we pay attention to social issues and turn them into business situations. Moreover, many experts have stated theoretical solutions for it. However, in the supply chain and sourcing, so far, no research with an operational approach has looked at the social issues through the lens of strategic CSR and local clustering. Previous research has provided useful insights into sustainable and responsible purchasing. Nevertheless, the absence of a comprehensive model for creating shared value is still felt $[60,61]$.

Moreover, a model that creates shared value and long-term buyer-supplier benefits with a rational and legitimated perspective should be designed based on Porter and Kramer's [29] discussions on the next evolution of capitalism. Our research uses the latest strategies proposed by $[22,29,61]$ to present a mathematical model, including the sieve and selection of suppliers and order allocation. The details of the strategies for this study and how to use it in mathematical modeling are discussed in the next section.

\section{Methods and Materials}

Although the traditional and repetitive criteria such as cost, quality, and delivery time are considered vital criteria in most studies [62], they are not enough to build trust and commitment between the buyer and the supplier to create a long-term communication plan. In this regard, the Spekman model [21] offered two main steps for selecting suppliers: first, collecting complete information based on different criteria from current, domestic, and foreign suppliers and sieving them to create a cluster of potential suppliers for a strategic partnership; second, reviewing and analyzing the strategic partnership to select the leading partner to form a long-term relationship with (Figure 4). 
Current Suppliers

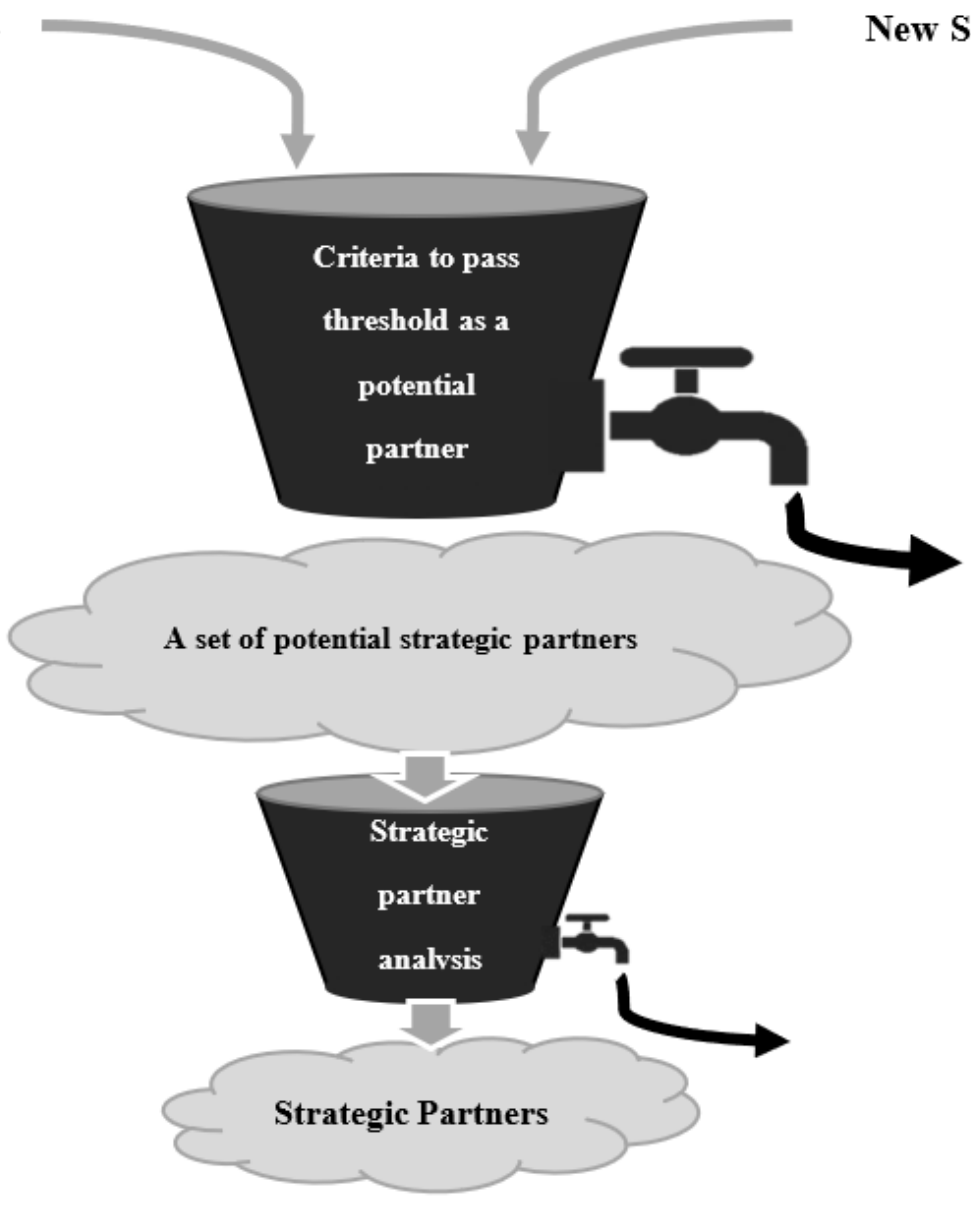

New Suppliers

Figure 4. Selecting strategic partners.

The paper's model is developed by reviewing and using the "Updater" strategy in the Lindgreen et al. [63] paper. Before we go into mathematical models and explanations of this section, we briefly review the strategies outlined in the mentioned article. By and large, they claim their research purpose as follows: first, explore the purchasing strategies of the company in the field of supply relations, besides finding which strategy differs according to the complexities of the buyer-supplier relationship with the company's buying goals. Besides, they categorized the strategies into two dimensions. The first dimension is the complexity of relationships interconnected in three parts of the transactional exchange, relational partnership, and network collaboration and then from the viewpoint of the purchase target, which is divided into two parts: purchasing effectiveness and purchasing efficiency. The main strategies proposed in this study are shown in Table 1.

Table 1. Purchasing strategies. Adapted with permission from ref [63]. 2009, Senja Svahn and Mika Westerlund.

\begin{tabular}{cccc}
\hline & & \multicolumn{2}{c}{ Goals and Targets of the Purchasing } \\
\cline { 3 - 4 } & & Efficiency & Effectiveness \\
\hline Relationship & Transactional Exchange & Price Minimization & Adaptor \\
Complexity between & Relational Partnership & Bargaining & Projector \\
Buyer and Supplier & Collaboration Network & Clockwise & Updater \\
\hline
\end{tabular}

Each strategy refers to specific cases; refer to the reference article for more information. The most elaborated strategy is the "Updater" strategy, which deals with the effects of the buying strategy in a long-term relationship. This strategy is based on continuous collabo- 
ration and networking in research and development projects. The nature of "Updater" is a network rather than a bilateral relationship. This kind of partner collaboration leads to more adaptation and open knowledge sharing.

\section{Shared Value Network Creation}

Before explaining the model, a fundamental question needs to be answered. Why and how is shared value creation used in this research? One strategic alternative to social responsibility that leads to shared value creation is developing local industrial clusters and strengthening their members by outsourcing or purchasing products and services. By enabling local cluster development (supporting other companies, local organizations, infrastructure, and academic programs), companies can strengthen local capabilities and assets [64].

Nowadays, establishing the advent of industrial clusters in outsourcing and purchasing is one of the most potent ways to create shared value. The employer of this research is the largest pharmaceutical holding company in Iran, and if it selects suppliers of industrial clusters for its products, the result is a flourishing in production and the inflow of a large amount of money into the area where the cluster is located.

Over time, if long-term relationships are established with these suppliers, the mentioned cluster will develop in many ways, such as education, transportation, product development, and innovation. What increases desirability is the company's lack of need for unrelated costs in traditional social responsibility activities, the non-strategic form (outside of shared value and strategic social responsibilities) leading the company to noncore missions and non-strategic activities. Therefore, based on Porter and Kramer [29] and strategic corporate social responsibility [65], this research develops industrial clusters through outsourcing and purchasing. Based on the views present in this study, the stages of formation to problem-solving can be defined as follows:

Phase 1: Supplier clustering: In this phase, a large amount of information about potential suppliers is first collected, and according to experts, based on the two criteria of geographical area and suppliers' connectivity with each other, clusters are determined whose members have high communication and short geographical distance. Choosing a cluster in a geographical area with members interacting creates opportunities for suppliers and the environment differently. In practice, a network of suppliers develops many products while also providing opportunities for its geographical area to increase knowledge and employment.

Phase 2: Sieving model: The selection of one (or more) cluster is designed based on knowledge criteria and the "Updater" strategy. The model is designed to examine and select the best cluster from different aspects. The variables within this model are binary variables for choosing clusters and companies. The model can select one or more clusters and select or reject suppliers within the selected cluster. Because all suppliers in a cluster may not have the necessary conditions, it is possible to select better suppliers from the selected clusters. The main criteria of this model are generally divided into two categories: communication and knowledge. Communication variables describe how much a supplier wants to build long-term communication in the supply network. Criteria of knowledge also deal with the level of activity and scientific infrastructure of a supplier. The output of this model is one or more selected clusters within the selected suppliers with the best performance in the supply network.

Phase 3: Purchase model: The mathematical purchasing model is formed after selecting the suppliers. The required data are collected from suppliers, and the model is executed. By and large, the purchasing model seeks to determine the number of purchases and outflows in multiple periods and determines which products, from which supplier, in which period, and to what extent they should be purchased. Besides, the buying model is a multi-product model. In addition to the cost criteria, there are constraints to distribute purchases and outsourcing among different suppliers, and in a way, orders are distributed 
throughout the network by considering optimism. In this model, production within the company is also considered.

Based on the supplier selection process that Spekman [21] presented and the views discussed earlier $[28,29,63]$, we developed a three-step decision-making model (Figure 5) including two mathematical models:

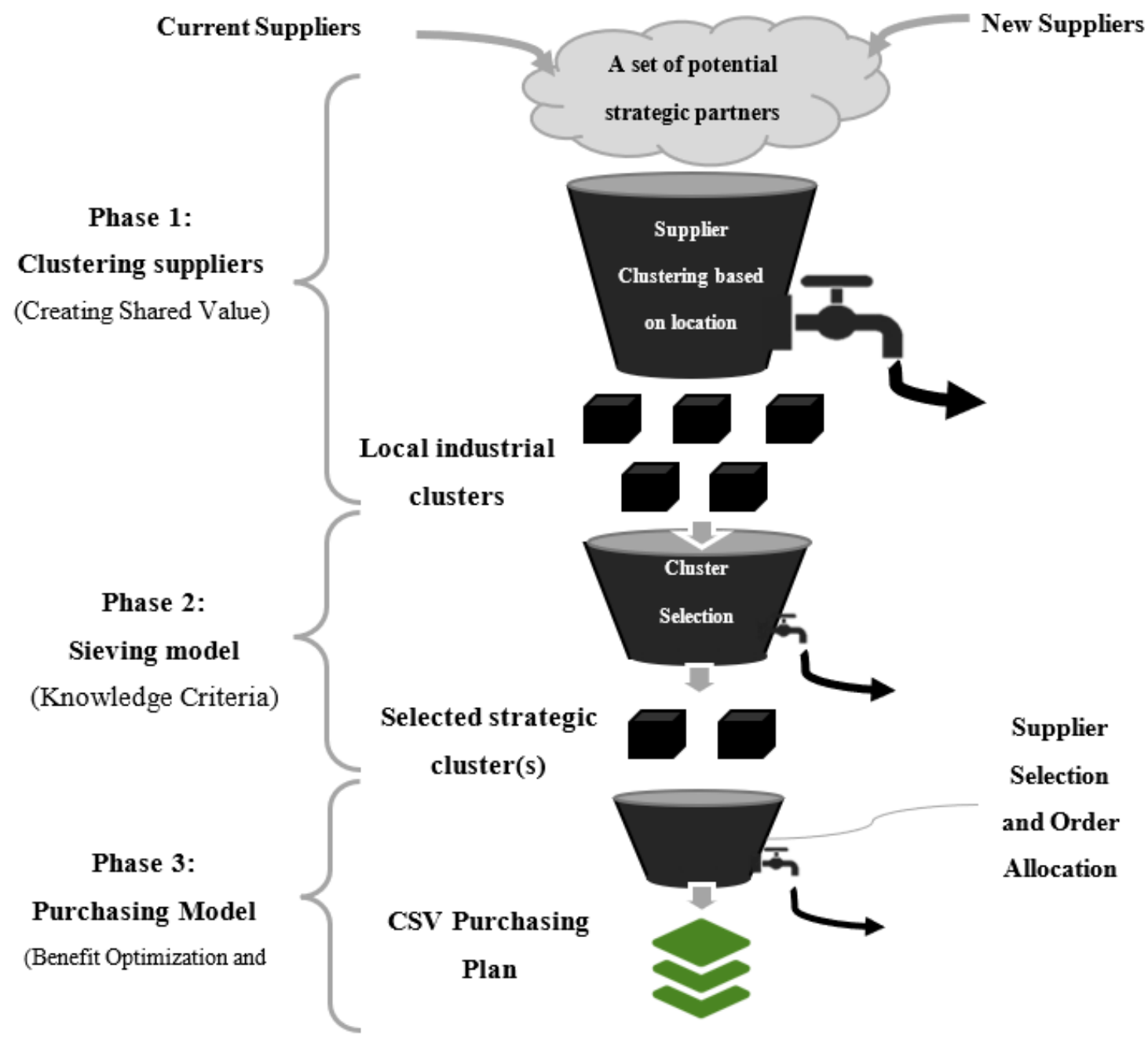

Figure 5. Conceptual model of shared value network creation.

Sieving model: In the first model, using updated criteria in the strategy and using the data collected by the suppliers, the optimal linear programming optimization model was developed to sieve the suppliers.

According to the industry and experts' opinions, criteria were selected to design a sieving model of the literature and some criteria under study. The criteria are the ease of communication index (openness) $[63,66,67]$, index of the patents published in the last five years [68], index of the articles published in the last five years $[63,66,69]$, index of the number of new products introduced in the last five years [1], production capacity index $[63,66,69]$, technology level index [66], knowledge infrastructure index $[63,66,69]$, scientific activity index [70], number of R\&D employees index (added by experts), and index of R\&D budget [71]. Based on these, the model was made, and after correction, it was approved by the experts. The indices, parameters, and variables of the sieving model are as follows: 
Indices:

j Index of suppliers.

Parameters:

$P T j \quad$ The patents printed by supplier $j$ in the last five years.

$A R j \quad$ Articles published by supplier $j$ in the last five years.

$O P j$ Openness index, information sharing rate.

$W P$ The penalty of the minus shortage R\&D personnel variable of goal programming constraint.

$C P i \quad$ Supplier $j$ capacity.

$R D i \quad$ Number of R\&D personnel supplier $j$.

$R D^{\prime} \quad$ The goal of R\&D personnel of suppliers.

$C P^{\prime} \quad$ Minimum total capacity required by suppliers for a period.

$\mathrm{NU}$ Minimum number of suppliers to be selected by the model.

IFj Provider knowledge infrastructure index $j$.

ASj The amount of attendance, activity, and dynamism in scientific assemblies and festivals.

$N E j \quad$ The number of new products entered into the market over the past five years.

TCj Levels of technology used in production.

BGj R\&D budget.

\section{Variables:}

fj Zero and one, select (one) or no selection (zero) supplier $j$.

dj The minus shortage variable of R\&D personnel of goal programming constraint.

$$
\begin{aligned}
\operatorname{Max}= & \sum_{j=1}^{J} P T_{j} f_{j} Y_{i}+\sum_{j=1}^{J} A R_{j} f_{j} Y_{i}+\sum_{j=1}^{J} O P_{j} f_{j} Y_{i}+\sum_{j=1}^{J} I F_{j} f_{j} Y_{i}+\sum_{j=1}^{J} T C_{j} f_{j} Y_{i} \\
& +\sum_{j=1}^{J} A S_{j} f_{j} Y_{i}+\sum_{j=1}^{J} N E_{j} f_{j} Y_{i}+\sum_{j=1}^{J} B G_{j} f_{j} Y_{i}-W P_{1} d_{1 j}^{-}-W P_{2} d_{2 j}^{-}
\end{aligned}
$$

Subject to :

$$
\begin{gathered}
\sum_{j=1}^{J} R D_{j} f_{j} Y_{i}+d_{1 j}^{-}-d_{1 j}^{+}=R D \prime \\
\sum_{j=1}^{J} C P_{j} f_{j} Y_{i}+d_{2 j}^{-}-d_{2 j}^{+}=C P \text { ' } \\
\sum_{j=1}^{J} Y_{i} \leq N U \\
f_{j}, Y_{i} \in\{0,1\} \\
G \times P D \times V: d_{2 j}^{-}, d_{2 j}^{+}, d_{1 j}^{-}, d_{1 j}^{+}
\end{gathered}
$$

Purchasing model: In the second model, demand information, costs, and capacity of selected suppliers in the first model for purchasing are formulated using a non-linear optimal mathematical model. This model is designed considering long-term relationships with these suppliers.

The variables of the mathematical purchasing model were obtained by interviewing the company's experts. It was also revealed that the model should be designed to make a fair distribution in the periodic purchases. Consequently, the network will be better created, encouraging competitive tensions productively [72].

Accordingly, in addition to the constraints of ordering and warehousing, a separate constraint was considered (10) to distribute purchases among selected suppliers. For the model to choose among suppliers and be more flexible, goal programming variables are defined in the objective function and constraint (10). For these variables, a penalty was considered that determines the degree of flexibility of the model in the selection. The higher the fine, the lower the cost of optimization. This is an indirect cost that the decision-maker is willing to bear in the absence of contact with other suppliers, and the decision-maker 
himself determines the amount. The indices, parameters, and variables of the first model are:

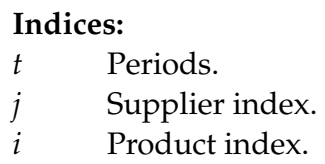

$$
\begin{aligned}
& \text { Min }=\sum_{i=1}^{n} \sum_{t=1}^{T} K_{i} \times Y_{i t}+\sum_{j=1}^{m} \sum_{t=1}^{T} O_{j} \times G_{j t}+\sum_{i=1}^{n} \sum_{j=1}^{m} \sum_{t=1}^{T} P_{j i t} \times U_{j i t} \times Z_{j i t} \\
& +\sum_{i=1}^{n} \sum_{j=1}^{m} \sum_{t=1}^{T} C_{i t} \times Q_{i t} \times Y_{i t}+\sum_{j=1}^{m} W \times d_{j}^{-} \\
& \sum_{i=1}^{n} Z_{j i t} \leq n \times G_{j t} \quad \text { for } j=1,2, \ldots, M ; t=1,2, \ldots, T \text {; } \\
& \sum_{j=1}^{m} U_{j i t} Z_{j i t}+Q_{i t} Y_{i t} \geq D_{i t}\left(1+S S_{i t}\right) \quad \text { for } i=1,2, \ldots, N ; t=1,2, \ldots, T \text {; } \\
& \sum_{t=1}^{T} G_{j t}+d_{j}^{-}-d_{j}^{+}=\left[\frac{T \times n}{m}\right] \quad \text { for } j=1,2, \ldots, M ; i=1,2, \ldots, N ; \\
& U_{j i t} Z_{j i t} \leq L_{j i t} \\
& Q_{i t} \leq M_{i} \\
& d_{j}^{-} \times d_{j}^{+}=0 \\
& Z_{j i t}, Y_{i t}, G_{j t} \in\{0,1\} \\
& U_{j i t}, Q_{i t}, d_{j}^{-}, d_{j}^{+} \in \mathbb{Z}
\end{aligned}
$$

Although the above strategic model alienates us from the optimal cost model solution by adding a proposition to the objective function and a constraint, it also enhances our relationship with selected suppliers in the long term. The sieving model selected suppliers based on knowledge criteria, knowledge sharing, and research and development. As a result, it is expected that more knowledge sharing will occur with the strengthening of the relationship between the supplier and the buyer, and reliable planning can be carried out for this purpose.

\section{Results}

As explained in the previous section, the initial model was written using Porter and Kramer [28], Porter and Kramer [29], and Lindgreen et al.'s [63] strategic foundations to select an industrial cluster for long-term and effective outsourcing that brings many benefits 
to buyers and suppliers, simultaneously. The consequences of applying these strategies will be discussed in detail in conclusion.

To implement the sieving model, data related to the model were collected, which are shown in Table 2. Three geographical clusters were formed based on Figure 2 and the existing infrastructure in the provinces. These three clusters, Fars, Alborz, and Markazi Provinces, had many social challenges; some of them are shown in Table 2. Since companies are mostly reluctant to share their information, obtaining some of it has not been easy. Regarding the criteria for which it was impossible to collect accurate data with the consent of the experts, we collected them based on the opinions of experts familiar with those companies. As a result, in Table 2, some criteria (openness index, knowledge infrastructure, technology level, and scientific communities) ranged from 1 to 9 are judicial data collected by experts' opinions. Also there are some related data to run a goal programming mathematical model shown in Table 3.

Table 2. Clusters' supplier data (strategic sieving).

\begin{tabular}{|c|c|c|c|c|c|c|c|c|c|c|}
\hline & & $\begin{array}{l}\text { Printed } \\
\text { Patents }\end{array}$ & $\begin{array}{l}\text { Published } \\
\text { Articles }\end{array}$ & $\begin{array}{l}\text { Openness } \\
\text { INDEX }\end{array}$ & $\begin{array}{c}\text { R\&D } \\
\text { Personnel }\end{array}$ & $\begin{array}{l}\text { Knowledge } \\
\text { Infrastructure }\end{array}$ & $\begin{array}{c}\text { Scientific } \\
\text { Communities }\end{array}$ & $\begin{array}{c}\text { New } \\
\text { Products }\end{array}$ & $\begin{array}{l}\text { Technology } \\
\text { Levels }\end{array}$ & $\begin{array}{l}\text { R\&D } \\
\text { Budget }\end{array}$ \\
\hline \multirow{6}{*}{ 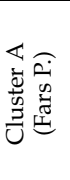 } & Company A1 & 2 & 12 & 8 & 4 & 1 & 5 & 10 & 4 & 120 \\
\hline & Company A2 & 1 & 14 & 4 & 3 & 2 & 4 & 6 & 3 & 230 \\
\hline & Company A3 & 2 & 13 & 5 & 5 & 3 & 4 & 11 & 5 & 300 \\
\hline & Company A4 & 4 & 16 & 5 & 4 & 5 & 3 & 6 & 6 & 250 \\
\hline & Company A5 & 3 & 9 & 2 & 2 & 3 & 3 & 7 & 3 & 190 \\
\hline & Company A6 & 7 & 10 & 4 & 5 & 2 & 4 & 10 & 4 & 200 \\
\hline \multirow{6}{*}{ 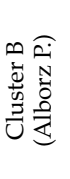 } & Company B1 & 3 & 11 & 2 & 2 & 3 & 6 & 4 & 8 & 130 \\
\hline & Company B2 & 4 & 21 & 2 & 3 & 8 & 5 & 6 & 4 & 270 \\
\hline & Company B3 & 2 & 12 & 5 & 2 & 4 & 3 & 4 & 2 & 120 \\
\hline & Company B4 & 0 & 18 & 8 & 4 & 5 & 3 & 3 & 4 & 100 \\
\hline & Company B5 & 8 & 28 & 1 & 6 & 7 & 7 & 14 & 5 & 320 \\
\hline & Company B6 & 2 & 20 & 5 & 3 & 6 & 4 & 6 & 2 & 200 \\
\hline \multirow{6}{*}{ 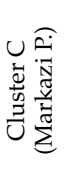 } & Company C1 & 4 & 32 & 4 & 5 & 8 & 9 & 20 & 6 & 360 \\
\hline & Company C2 & 5 & 18 & 5 & 2 & 4 & 6 & 12 & 7 & 200 \\
\hline & Company C3 & 4 & 13 & 7 & 2 & 5 & 5 & 10 & 8 & 180 \\
\hline & Company C4 & 6 & 12 & 6 & 3 & 3 & 3 & 4 & 6 & 220 \\
\hline & Company C5 & 3 & 11 & 5 & 4 & 4 & 3 & 8 & 7 & 200 \\
\hline & Company C6 & 2 & 16 & 7 & 4 & 5 & 2 & 9 & 4 & 250 \\
\hline
\end{tabular}

Table 3. Goal programming data of cluster selection (sieving model).

\begin{tabular}{cc}
\hline & Value \\
\hline Negative goal variable penalty & 2 \\
Personnel constraint goal & 25 \\
Maximum selected clusters & 1 \\
\hline
\end{tabular}

\subsection{Data Normalization of the Sieving Model}

Since the data collected for the objective function of the initial model are not of the same type (e.g., cost), the data should be entered into the model after normalization. Accordingly, the data were modeled using linear normalization [73] and were ready to enter scales.

$$
\begin{gathered}
n_{i j}=\frac{a_{i j}}{\operatorname{Max}\left(a_{i j}\right)} \\
n_{i j}=\frac{\operatorname{Min}_{i}\left(a_{i j}\right)}{a_{i j}} \\
n_{i j}=1-\frac{a_{i j}}{\operatorname{Max}_{i}\left(a_{i j}\right)}
\end{gathered}
$$

In this method, the positive indices using Equation (16) and the negative indices using Equation (17) are scaled. If all indices are negative, Equation (18) can also scale the indices. In our model, all indices were positive, and Equation (16) were used. 
The normalized data are listed in Table 4. Only the data on the number of R\&D personnel need to be normalized since the planning in the model is objective, and these data are only used in constraints.

Table 4. Normalized data of the sieving model.

\begin{tabular}{|c|c|c|c|c|c|c|c|c|c|}
\hline & $\begin{array}{l}\text { Published } \\
\text { Patents }\end{array}$ & $\begin{array}{l}\text { Published } \\
\text { Articles }\end{array}$ & $\begin{array}{l}\text { Openness } \\
\text { Index }\end{array}$ & $\begin{array}{c}\text { R\&D } \\
\text { Personnel }\end{array}$ & $\begin{array}{l}\text { Knowledge } \\
\text { Infrastructure }\end{array}$ & $\begin{array}{l}\text { Scientific } \\
\text { Activities }\end{array}$ & $\begin{array}{c}\text { New } \\
\text { Products }\end{array}$ & $\begin{array}{l}\text { Technology } \\
\text { Levels }\end{array}$ & $\begin{array}{c}\text { R\&D } \\
\text { Budget }\end{array}$ \\
\hline Comp. A1 & 0.25 & 0.375 & 1 & 0.666667 & 0.125 & 0.555556 & 0.5 & 0.5 & 0.333333 \\
\hline Comp. A2 & 0.125 & 0.4375 & 0.5 & 0.5 & 0.25 & 0.444444 & 0.3 & 0.375 & 0.638889 \\
\hline Comp. A3 & 0.25 & 0.40625 & 0.625 & 0.833333 & 0.375 & 0.444444 & 0.55 & 0.625 & 0.833333 \\
\hline Comp. A4 & 0.5 & 0.5 & 0.625 & 0.666667 & 0.625 & 0.333333 & 0.3 & 0.75 & 0.694444 \\
\hline Comp. A5 & 0.375 & 0.28125 & 0.25 & 0.333333 & 0.375 & 0.333333 & 0.35 & 0.375 & 0.527778 \\
\hline Comp. A6 & 0.875 & 0.3125 & 0.5 & 0.833333 & 0.25 & 0.444444 & 0.5 & 0.5 & 0.555556 \\
\hline Comp. B1 & 0.375 & 0.34375 & 0.25 & 0.333333 & 0.375 & 0.666667 & 0.2 & 1 & 0.361111 \\
\hline Comp. B2 & 0.5 & 0.65625 & 0.25 & 0.5 & 1 & 0.555556 & 0.3 & 0.5 & 0.75 \\
\hline Comp. B3 & 0.25 & 0.375 & 0.625 & 0.333333 & 0.5 & 0.333333 & 0.2 & 0.25 & 0.333333 \\
\hline Comp. B4 & 0 & 0.5625 & 1 & 0.666667 & 0.625 & 0.333333 & 0.15 & 0.5 & 0.277778 \\
\hline Comp. B5 & 1 & 0.875 & 0.125 & 1 & 0.875 & 0.777778 & 0.7 & 0.625 & 0.888889 \\
\hline Comp. B6 & 0.25 & 0.625 & 0.625 & 0.6 & 0.75 & 0.444444 & 0.3 & 0.25 & 0.555556 \\
\hline Comp. C1 & 0.5 & 1 & 0.5 & 1 & 1 & 1 & 1 & 0.75 & 1 \\
\hline Comp. C2 & 0.625 & 0.5625 & 0.625 & 0.5 & 0.5 & 0.666667 & 0.6 & 0.875 & 0.555556 \\
\hline Comp. C3 & 0.5 & 0.40625 & 0.875 & 0.5 & 0.625 & 0.555556 & 0.5 & 1 & 0.5 \\
\hline Comp. C4 & 0.75 & 0.375 & 0.75 & 0.75 & 0.375 & 0.333333 & 0.2 & 0.75 & 0.611111 \\
\hline Comp. C5 & 0.375 & 0.34375 & 0.625 & 1 & 0.5 & 0.333333 & 0.4 & 0.875 & 0.555556 \\
\hline Comp. C6 & 0.25 & 0.5 & 0.875 & 1 & 0.625 & 0.222222 & 0.45 & 0.5 & 0.694444 \\
\hline
\end{tabular}

\subsection{Selection of Clusters}

Based on the input data in the first model (cluster selection) discussed in the previous section, the problem with the form of the sieving model presented in the previous chapter was formulated and solved in Lingo and MATLAB (genetic algorithm) software. The optimal solution obtained from both software, given the nonlinearity of the model, shows that the optimal point is the final solution. The answers are:

Based on the initial model (Table 5), cluster C (Markazi Province) is selected as the cluster at this stage, and the data of the companies in that cluster in the input data (Tables 6-8) are used to run and execute the genetic algorithm.

Table 5. Results of sieving model.

\begin{tabular}{|c|c|c|c|c|c|c|c|c|c|c|c|}
\hline Description & Variable & Value & Description & Variable & Value & Description & Variable & Value & Description & Variable & Value \\
\hline \multirow{6}{*}{ 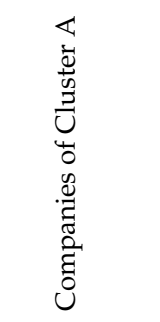 } & & & \multirow{6}{*}{ 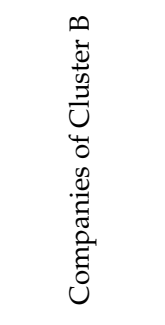 } & & & ث & & & \multirow{6}{*}{$\begin{array}{c}\text { Cluster no.1 } \\
\text { Cluster no. } 2 \\
\text { Cluster no.3 } \\
\text { Deviation from } \\
\text { negative goal } \\
\text { Deviation from } \\
\text { positive goal }\end{array}$} & & \\
\hline & $\begin{array}{l}\mathrm{F} 1 \\
\mathrm{~F} 2\end{array}$ & $\begin{array}{l}0 \\
0\end{array}$ & & $\begin{array}{l}\text { F7 } \\
\text { F8 }\end{array}$ & $\begin{array}{l}0 \\
0\end{array}$ & 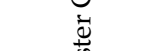 & $\begin{array}{l}\text { F13 } \\
\text { F14 }\end{array}$ & $\begin{array}{l}1 \\
0\end{array}$ & & $\begin{array}{l}\text { F19 } \\
\text { F20 }\end{array}$ & $\begin{array}{l}0 \\
0\end{array}$ \\
\hline & F3 & 0 & & F9 & 0 & $\stackrel{\infty}{=}$ & F15 & 1 & & $\mathrm{~F} 21$ & 1 \\
\hline & $\mathrm{F} 4$ & 0 & & F10 & 0 & 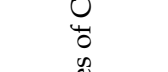 & F16 & 1 & & F22 & 5 \\
\hline & F5 & 0 & & F11 & 0 & : & F17 & 1 & & \multirow[t]{2}{*}{ F23 } & \multirow[t]{2}{*}{0} \\
\hline & F6 & 0 & & F12 & 0 & हृ & F18 & 1 & & & \\
\hline
\end{tabular}


Table 6. The purchase price, capacity, and order cost (purchasing model).

\begin{tabular}{lccccc}
\hline & Com. C1 & Com. C3 & Com. C4 & Com. C5 & Com. C6 \\
\hline Supplement (1) unit price & 16,000 & 15,500 & 15,350 & 15,800 & 16,500 \\
Supplement (2) unit price & 21,200 & 22,700 & 20,900 & 22,150 & 21,800 \\
Supplement (3) unit price & 12,900 & 13,250 & 12,250 & 12,750 & 13,500 \\
Supplement (4) unit price & 36,700 & 36,000 & 35,000 & 37,300 & 35,650 \\
Supplement (1) capacity & 1300 & 2470 & 2860 & 780 & 1560 \\
Supplement (2) capacity & 2730 & 2990 & 3900 & 2340 & 2990 \\
Supplement (3) capacity & 2080 & 2600 & 3380 & 2600 & 1950 \\
Supplement (4) capacity & 5200 & 4550 & 3900 & 2860 & 5070 \\
Suppliers' order cost & $4,400,000$ & $5,478,000$ & $4,840,000$ & 5280,000 & $6,380,000$ \\
\hline
\end{tabular}

Table 7. Product demand $i$ in period $t$.

\begin{tabular}{lcccccccc}
\hline & Period 1 & Period 2 & Period 3 & Period 4 & Period 5 & Period 6 & Period 7 & Period 8 \\
\hline Supplement (1) & 1200 & 1320 & 1680 & 2280 & 2040 & 1440 & 1080 & 960 \\
Supplement (2) & 2760 & 2640 & 2580 & 2520 & 2760 & 2880 & 2640 & 2400 \\
Supplement (3) & 2160 & 2160 & 2160 & 2160 & 2160 & 2160 & 2160 & 2160 \\
Supplement (4) & 5760 & 6000 & 6240 & 6600 & 6240 & 6000 & 5640 & 5400 \\
\hline
\end{tabular}

Table 8. Inbound production data.

\begin{tabular}{lccccc}
\hline & $\begin{array}{c}\text { Product Cost } \\
\text { (Per Unit) }\end{array}$ & Set Up Cost & $\begin{array}{c}\text { Company Capacity } \\
\text { (Per Month) }\end{array}$ & $\begin{array}{c}\text { Safety Stock \% } \\
\text { (Per Month) }\end{array}$ & $\begin{array}{c}\text { Inventory Cost } \\
\text { (Per Month) }\end{array}$ \\
\hline Supplement (1) & 14,000 & $7,200,000$ & 1600 & 7 & 120 \\
Supplement (2) & 20,200 & $4,500,000$ & 2600 & 7 & 240 \\
Supplement (3) & 11,400 & $6,500,000$ & 2400 & 7 & 190 \\
Supplement (4) & 33,500 & $5,400,000$ & 5600 & 7 & 300 \\
\hline
\end{tabular}

\subsection{Purchasing Model Data Collection}

The purchasing model is a non-linear integer mathematical model and NP-HARD. Model decision variables are all integers and correspond to each purchase quantity variable, and there is a zero and one decision variable that indicates buy/produce or no buy/produce.

The original model had to be modified to a standard genetic form in MATLAB. These changes are: (A) all constraints are equal to zero; (B) the objective function is in the form of minimization; $(\mathrm{C})$ determine the range of variables in the model; (D) determine integer variables; (E) determine the number of variables.

Moreover, given that we were dealing with a non-linear example with many variables (about 500), a variety of mutations and intersection functions had to be tested on problem solving. In this research, we have obtained different results tens of times using the final model and different functions and settings.

\subsection{Genetic Algorithm Settings}

Among the different settings of the genetic algorithm, some settings that give more logical answers are listed below (Table 9). The Gaussian operator for mutation was avoided because it is used in unlimited problems [74,75]. Moreover, intermediate intersection was not used for intersection operators because of its use for large-scale linear problems [76].

Among the various implementations in Table 10, the best execution of each setting is selected and presented in Appendix A. It should be noted that most of the responses of a particular type of setting were not significantly different in terms of the objective function and the values obtained. The results are presented in the tables based on the number of runs of the genetic algorithm, and the variable names are mentioned as in the model. 
Table 9. Genetic algorithm settings in different implementations.

\begin{tabular}{cccc}
\hline$\#$ & Crossover & Mutation & Pop-Size \\
\hline 1 & Constraint Dependent & Constraint Dependent & 10,000 \\
2 & Uniform & Constraint Dependent & 5000 \\
3 & Constraint Dependent & Constraint Dependent & 10,000 \\
4 & Adaptive Feasible & Two Point & 10,000 \\
5 & Adaptive Feasible & Scattered & 20,000 \\
6 & Constraint Dependent & Single Point & 10,000 \\
7 & Constraint Dependent & Scattered & 10,000 \\
\hline
\end{tabular}

Table 10. Summary table of the objective function and goal variables.

\begin{tabular}{|c|c|c|c|c|c|c|c|}
\hline & Run \#1 & Run \#2 & Run \#3 & Run \#4 & Run \#5 & Run \#6 & Run \#7 \\
\hline Crossover & $\begin{array}{l}\text { Constraint } \\
\text { Dependent }\end{array}$ & Uniform & $\begin{array}{l}\text { Constraint } \\
\text { Dependent }\end{array}$ & $\begin{array}{l}\text { Adaptive } \\
\text { Feasible }\end{array}$ & $\begin{array}{l}\text { Adaptive } \\
\text { Feasible }\end{array}$ & $\begin{array}{l}\text { Constraint } \\
\text { Dependent }\end{array}$ & $\begin{array}{l}\text { Constraint } \\
\text { Dependent }\end{array}$ \\
\hline Mutation & $\begin{array}{l}\text { Constraint } \\
\text { Dependent }\end{array}$ & $\begin{array}{l}\text { Constraint } \\
\text { Dependent }\end{array}$ & Heuristic & Two Point & Scattered & Single Point & Scattered \\
\hline D1 & 1 & 2 & 3 & 0 & 0 & 0 & 3 \\
\hline D2 & 2 & 3 & 2 & 1 & 0 & 3 & 3 \\
\hline D3 & 2 & 0 & 3 & 2 & 4 & 0 & 3 \\
\hline D4 & 3 & 4 & 1 & 2 & 2 & 5 & 0 \\
\hline D5 & 0 & 2 & 1 & 3 & 4 & 0 & 2 \\
\hline Epochs & 2334 & 1176 & 982 & 975 & 860 & 1248 & 2057 \\
\hline Objective Function & $1.59 \times 10^{9}$ & $2.10 \times 10^{9}$ & $1.72 \times 10^{9}$ & $1.98 \times 10^{9}$ & $1.86 \times 10^{9}$ & $1.78 \times 10^{9}$ & $1.77 \times 10^{9}$ \\
\hline Outsource Lot & 78,123 & 70,693 & 80,917 & 75,001 & 84,117 & 81,742 & 73,572 \\
\hline Inbound Lot & 20,271 & 27,647 & 20,117 & 23,058 & 14,264 & 16,699 & 24,808 \\
\hline Total & 98,394 & 98,340 & 101,034 & 98,059 & 98,381 & 98,441 & 98,380 \\
\hline
\end{tabular}

Based on the results (Appendix A), one can analyze the model objectives outlined in Section 3. Based on these goals, the answer is that we aim to minimize the objective function while at the same time providing a diverse portfolio of suppliers that guarantee long-term, stable relationships with suppliers in outsourcing products. As shown in Table 10, in terms of the degree of the objective function, the one executed with the constraint-dependent operators provided the more desirable answer. In this respect, the three, six, and seven solutions are in the next rank in the objective function.

In cart dispersion, one, three, and four are more desirable, and the number of objective variables is closer to zero and more dispersed. Accordingly, and considering the same iterations of the answer with the same settings, it can be concluded that answers one and then three are more favorable with the dependent constraint operators (Table 10).

Moreover, in Figure 6, after normalizing the numbers, it is shown what differences among each implementation of the algorithm (due to its different settings) have been made. As illustrated, Run \#6 shows a good situation in all cases, which means the more it tends to be minimum, the more efficiency is obtained. It should be noted that an index called variance has been added to the chart that shows the distribution of purchases among suppliers. 


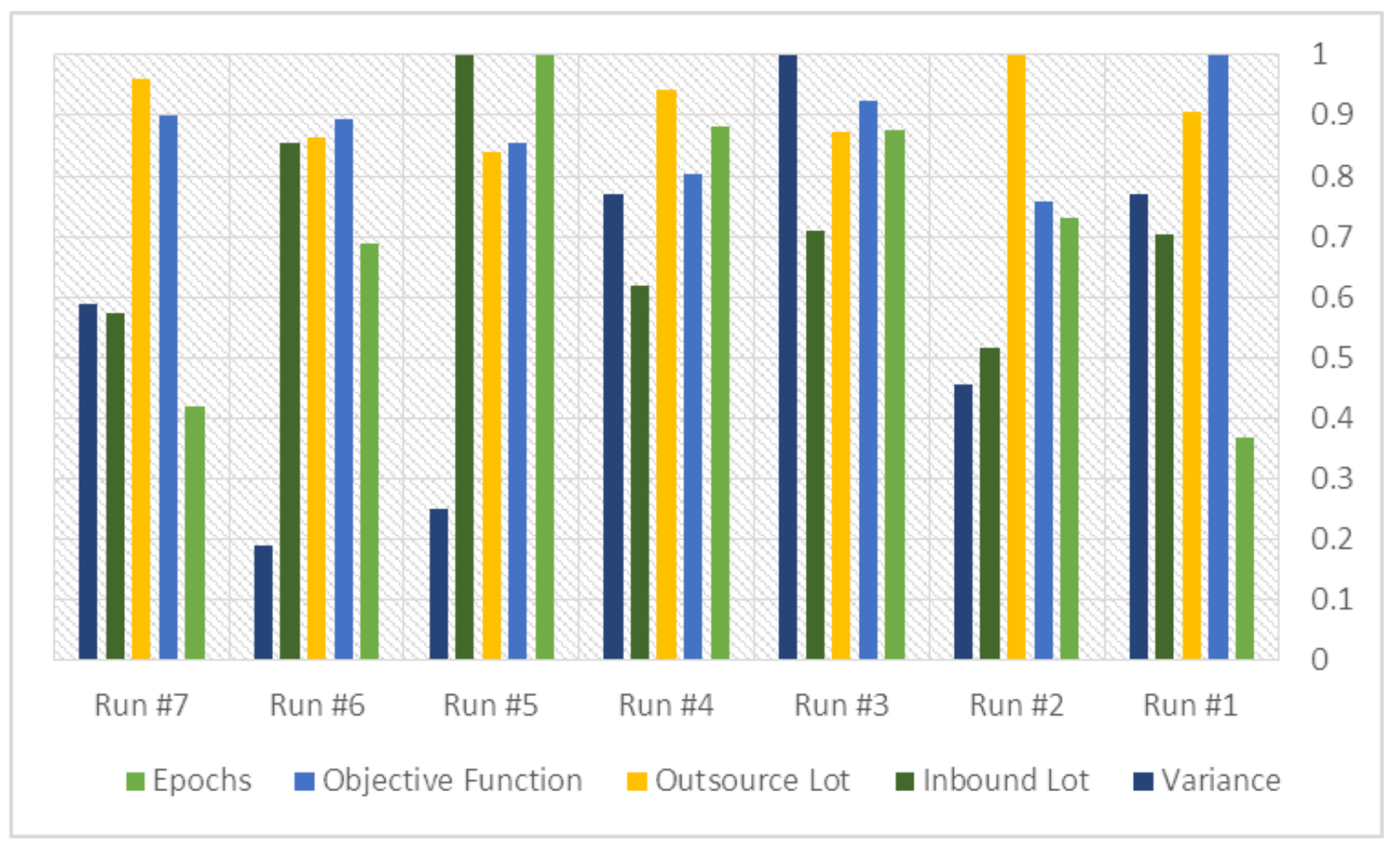

Figure 6. Performance comparison of the different settings (normalized).

\subsection{Discussions and Managerial Insights}

The implementation of this research showed that sourcing and outsourcing based on the creation of common value help the circulation of capital and money in deprived areas. Although known as an industrial province, Central Province in Iran has a high unemployment rate and poverty. The development of the industrial pharmacy cluster in Markazi Province and the city of Arak (with three active companies) provides many employment opportunities for this region. The existence of two universities in Arak (one medical and one engineering) can provide human resources for this opportunity.

Although these models were implemented in the Iranian pharmaceutical industry, they can expand to other industries. For example, this model can manufacture electronic components, handicrafts, and food products. The main variables of the second model are considered in general and can be implemented in any industry. Moreover, the first model can be generalized to most industries, and its unnecessary parameters can be reduced as needed. It can also be said that this method of sourcing and these mathematical models can be used for other countries and offshoring. For instance, these models can be used as a basis for selection and purchase for Fairtrade [77,78] products.

As mentioned earlier, using this method of procurement, in the long run, can bring benefits to the company and its infrastructure (consisting of the partner companies, suppliers, and service providers) and the community (consisting of employees and people). Table 11 summarizes the benefits that can be obtained.

These results were obtained using a survey session after designing the model. First, three social responsibility experts in the buyer and supplier companies were interviewed, and possible results were obtained. Then, the possible results were discussed in the presence of representatives of each field (buyer company, suppliers, customers, and ordinary people: two persons from each group). The output of the results is written based on the consensus of the related members. 
Table 11. Long-term consequences based on experts' opinions.

\begin{tabular}{|c|c|c|c|c|}
\hline \multirow{2}{*}{ Long-Term Consequences } & \multicolumn{4}{|c|}{ Benefit Level } \\
\hline & Corporate & Suppliers & Employees & Society \\
\hline Investment focus in the industrial cluster geographic area & & Low & Moderate & High \\
\hline The emergence of new service and manufacturing jobs and related companies & & High & & High \\
\hline Creating shared value and strategic CSR replaces costly social responsibility & Very High & High & & \\
\hline Reduce the risk of ordering & Very High & Moderate & & \\
\hline Easy to access and cost reduction of raw materials & & High & & \\
\hline Strengthen knowledge sharing network & Very High & High & & \\
\hline Improving product quality by learning about new technologies & High & High & & Moderate \\
\hline Development of knowledge-based companies in the region & & High & & High \\
\hline Development of pharmaceutical-related specialties & & High & & High \\
\hline Focus on job search and ease of attracting human resources & Low & Very High & High & High \\
\hline Empowering the people of the region and trying to eliminate unemployment & & & Moderate & High \\
\hline Increase job security in the region and a more straightforward career path & & & Very High & Moderate \\
\hline Development of education systems & & & High & Very High \\
\hline Access to more support technical facilities and infrastructure & Moderate & High & & \\
\hline
\end{tabular}

\section{Conclusions}

One way to develop local industrial clusters is to strengthen outsourcing influenced by a shared value creation perspective. In the above model, the companies considered for outsourcing were first classified according to their geographical location, and one (or several) cluster(s) was selected. Establishing long-term relationships with a cluster and selecting them based on knowledge criteria can benefit the buyers. If clustering had not taken place, the only choices would have been based on criteria of knowledge, and most likely, suppliers would have been selected who were not in the geographical area. Furthermore, if we did not apply the knowledge criteria according to Lindgreen et al. [63] strategies, there would be no compelling reason to establish a sustaining and lasting relationship with selected suppliers. Therefore, it can be concluded that industrial clusters (shared value creation) and purchasing strategies in supply chain management can be used as a dominant view in decision making. What increases the desirability is the company's independence in the traditional social responsibility scenes, which takes away the company to the core mission.

Strategic CSR or CSV is an improved viewpoint of CSR [65] on the business that binds social needs and challenges to its core business and eliminates the need for a company to perform activities it does not specialize in, such as traditional CSR. Moreover, according to the predictions made by Porter and researchers in this field, creating shared value will be the basis of competitive advantage in the future [25]. This research is a step forward in spreading this concept and developing a model for purchasing decision making, with long-term and thought-provoking revenues compared to previous models. The model developed in this research was implemented and solved using a genetic algorithm in MATLAB software.

The innovations in the methodology of this research can be discussed from several perspectives that can be categorized and summarized. The most important feature of this research relates to the strategic choice of suppliers. In previous studies, the strategic selection of suppliers was not made by mathematical programming through the viewpoints of strategic CSR. Most of the approaches used in these studies were ranking and scoring approaches to select the best suppliers. Strategic modeling has not been found to add a specific strategy proposed in previous research to the mathematical model of lot sizing and supplier selection, and this is an essential innovation for future research.

Besides, paying attention to shared value creation strategies in operational decisionmaking and mathematical models is one of the innovations of this research. Although choosing an industrial cluster may reduce some of our cost-based optimizations, implementing this plan in a system will bring many long-term benefits to the community and the company. The company's benefits include strong relationships with suppliers, rapid quality development, lower shipping costs, and better and easier knowledge transfer. Furthermore, 
in previous studies, most theoretical issues have been addressed. In this study, several perspectives are combined. On the one hand, the company can produce some products. On the other hand, the company can provide some products while using high-capacity suppliers, establish long-term relationships, and then plan for innovation and knowledge sharing.

Despite the cooperation of experts, this research was limited for a couple of reasons. The most important limitation of the research was collecting data related to the criteria. Most suppliers provided opaque and inaccurate information, forcing us to rely more on experts' opinions and judgments. Future research is expected to concentrate more on the concept of shared value creation and strategic CSR. Although these concepts seem to be semantically related to traditional social responsibility, they are quite different in practice. Researchers are encouraged to discover innovative manners in creating shared value in the supply chain, in addition to fair resourcing. Among them is the evaluation of sub-suppliers. There may also be other manners to create shared value in different industries; therefore, basic industry-specific research to identify these opportunities can be given special attention in academic communities. In addition, it is recommended that this model be implemented on Fairtrade products.

Author Contributions: Conceptualization, M.K., A.T. and A.A.; methodology, M.K. and A.T.; software, M.K.; validation, M.H.-K., A.R.G. and A.T.; formal analysis, A.T. and M.H.-K.; investigation, A.A. and M.K.; resources, M.K., A.T. and A.A.; data curation, M.K.; writing-original draft preparation, A.A. and M.K.; writing-review and editing, A.T., M.H.-K. and M.R.; visualization, M.K. and M.R.; supervision, A.A.; project administration, A.R.G. All authors have read and agreed to the published version of the manuscript.

Funding: This research received no external funding.

Institutional Review Board Statement: Not applicable.

Informed Consent Statement: Not applicable.

Data Availability Statement: The data that support the findings of this study are available on request from the corresponding author.

Conflicts of Interest: The authors declare no conflict of interest. 
Appendix A. Purchasing Model Variables' Results in Several GA Implementations

\begin{tabular}{|c|c|c|c|c|c|c|c|c|c|c|c|c|c|c|c|c|c|c|c|c|c|c|c|}
\hline $\begin{array}{l}\text { Variable } \\
\text { Name }\end{array}$ & $\begin{array}{c}\text { Run } \\
\# 1\end{array}$ & $\begin{array}{c}\text { Run } \\
\# 2\end{array}$ & $\begin{array}{c}\text { Run } \\
\# 3\end{array}$ & $\begin{array}{c}\text { Run } \\
\# 4\end{array}$ & $\begin{array}{c}\text { Run } \\
\# 5\end{array}$ & $\begin{array}{c}\text { Run } \\
\# 6\end{array}$ & $\begin{array}{c}\text { Run } \\
\# 7\end{array}$ & $\begin{array}{c}\text { Variable } \\
\text { Name }\end{array}$ & $\begin{array}{c}\text { Run } \\
\# 1\end{array}$ & $\begin{array}{c}\text { Run } \\
\# 2\end{array}$ & $\begin{array}{c}\text { Run } \\
\# 3\end{array}$ & $\begin{array}{c}\text { Run } \\
\# 4\end{array}$ & $\begin{array}{c}\text { Run } \\
\# 5\end{array}$ & $\begin{array}{c}\text { Run } \\
\# 6\end{array}$ & $\begin{array}{c}\text { Run } \\
\# 7\end{array}$ & $\begin{array}{c}\text { Variable } \\
\text { Name }\end{array}$ & $\begin{array}{c}\text { Run } \\
\# 1\end{array}$ & $\begin{array}{c}\text { Run } \\
\# 2\end{array}$ & $\begin{array}{c}\text { Run } \\
\# 3\end{array}$ & $\begin{array}{c}\text { Run } \\
\# 4\end{array}$ & $\begin{array}{c}\text { Run } \\
\# 5\end{array}$ & $\begin{array}{c}\text { Run } \\
\# 6\end{array}$ & $\begin{array}{c}\text { Run } \\
\# 7\end{array}$ \\
\hline U111 & 0 & 87 & 0 & 0 & 0 & 509 & 0 & U545 & 0 & 0 & 868 & 0 & 1202 & 0 & 2007 & Z327 & 0 & 0 & 1 & 0 & 0 & 0 & 0 \\
\hline U112 & 907 & 0 & 0 & 0 & 1299 & 170 & 0 & U546 & 4022 & 4052 & 0 & 0 & 0 & 505 & 3857 & Z328 & 0 & 0 & 0 & 0 & 0 & 0 & 1 \\
\hline U113 & 0 & 0 & 0 & 0 & 0 & 0 & 0 & U547 & 4155 & 0 & 0 & 0 & 2345 & 0 & 2059 & Z331 & 0 & 1 & 0 & 0 & 1 & 1 & 0 \\
\hline U114 & 0 & 0 & 577 & 0 & 0 & 1277 & 873 & U548 & 0 & 0 & 3643 & 3773 & 523 & 0 & 3060 & Z332 & 1 & 0 & 1 & 0 & 0 & 0 & 0 \\
\hline U115 & 0 & 1185 & 0 & 0 & 0 & 0 & 402 & Q11 & 0 & 697 & 463 & 0 & 764 & 162 & 561 & Z333 & 0 & 1 & 0 & 0 & 1 & 1 & 0 \\
\hline U116 & 0 & 624 & 0 & 631 & 0 & 0 & 591 & Q12 & 0 & 1320 & 1110 & 0 & 0 & 0 & 0 & Z334 & 0 & 0 & 1 & 0 & 0 & 0 & 0 \\
\hline U117 & 774 & 479 & 1300 & 0 & 1080 & 854 & 0 & Q13 & 1222 & 477 & 0 & 0 & 0 & 0 & 919 & Z335 & 0 & 0 & 1 & 1 & 1 & 0 & 0 \\
\hline U118 & 0 & 0 & 1162 & 964 & 0 & 567 & 960 & Q14 & 583 & 804 & 0 & 1446 & 338 & 0 & 0 & Z336 & 0 & 1 & 0 & 0 & 0 & 0 & 1 \\
\hline U122 & 451 & 0 & 133 & 0 & 0 & 0 & 1044 & Q16 & 710 & 0 & 648 & 447 & 1441 & 480 & 0 & Z338 & 0 & 1 & 0 & 0 & 0 & 0 & 0 \\
\hline U123 & 1572 & 0 & 0 & 78 & 0 & 0 & 0 & Q17 & 0 & 0 & 0 & 966 & 0 & 0 & 0 & Z341 & 1 & 0 & 1 & 1 & 1 & 1 & 0 \\
\hline U124 & 0 & 0 & 0 & 1988 & 0 & 0 & 2214 & Q18 & 342 & 0 & 0 & 0 & 0 & 0 & 0 & Z342 & 1 & 1 & 0 & 1 & 0 & 0 & 0 \\
\hline U125 & 0 & 0 & 0 & 1288 & 1313 & 0 & 0 & Q21 & 1227 & 0 & 374 & 0 & 0 & 1770 & 2068 & Z343 & 0 & 1 & 1 & 0 & 0 & 1 & 1 \\
\hline U126 & 1346 & 0 & 2509 & 0 & 0 & 0 & 0 & Q22 & 1561 & 2592 & 0 & 0 & 0 & 1183 & 0 & Z344 & 0 & 1 & 1 & 1 & 1 & 0 & 1 \\
\hline U127 & 729 & 1539 & 0 & 0 & 0 & 0 & 1384 & Q23 & 1008 & 839 & 1532 & 0 & 0 & 0 & 0 & Z345 & 0 & 0 & 0 & 1 & 0 & 0 & 0 \\
\hline U128 & 0 & 0 & 956 & 1115 & 0 & 0 & 0 & Q24 & 0 & 0 & 2600 & 0 & 0 & 753 & 0 & Z346 & 1 & 0 & 1 & 1 & 0 & 0 & 0 \\
\hline U131 & 0 & 0 & 0 & 0 & 472 & 0 & 0 & Q25 & 0 & 448 & 2600 & 0 & 0 & 390 & 0 & Z347 & 0 & 0 & 0 & 1 & 0 & 0 & 0 \\
\hline U132 & 0 & 175 & 1983 & 0 & 953 & 0 & 0 & Q26 & 0 & 0 & 947 & 0 & 0 & 0 & 1324 & Z348 & 1 & 1 & 1 & 1 & 1 & 0 & 0 \\
\hline U133 & 0 & 0 & 0 & 0 & 0 & 0 & 0 & Q27 & 0 & 0 & 0 & 0 & 1929 & 255 & 1262 & Z411 & 0 & 0 & 1 & 1 & 0 & 0 & 0 \\
\hline U136 & 0 & 0 & 447 & 0 & 0 & 813 & 560 & Q32 & 0 & 1208 & 0 & 0 & 0 & 969 & 955 & Z414 & 0 & 0 & 0 & 0 & 0 & 0 & 1 \\
\hline U137 & 370 & 0 & 0 & 1782 & 0 & 0 & 0 & Q33 & 0 & 531 & 2400 & 0 & 317 & 0 & 0 & Z415 & 0 & 0 & 1 & 1 & 1 & 0 & 0 \\
\hline U138 & 0 & 0 & 1714 & 2020 & 1027 & 57 & 0 & Q34 & 1007 & 728 & 0 & 0 & 950 & 1274 & 0 & Z416 & 0 & 1 & 0 & 0 & 0 & 1 & 0 \\
\hline U141 & 0 & 0 & 0 & 0 & 1992 & 1806 & 447 & Q35 & 1514 & 863 & 0 & 797 & 0 & 390 & 1454 & Z417 & 1 & 0 & 0 & 0 & 0 & 1 & 1 \\
\hline U142 & 0 & 1794 & 0 & 0 & 3662 & 0 & 3394 & Q36 & 2070 & 470 & 0 & 1131 & 0 & 0 & 0 & Z418 & 1 & 0 & 0 & 0 & 0 & 0 & 0 \\
\hline U143 & 3894 & 1963 & 3096 & 1239 & 2408 & 0 & 3626 & Q37 & 0 & 0 & 0 & 0 & 0 & 435 & 0 & $\mathrm{Z} 421$ & 1 & 0 & 0 & 0 & 0 & 0 & 0 \\
\hline U144 & 4311 & 1666 & 2558 & 0 & 1652 & 383 & 0 & Q38 & 0 & 0 & 426 & 0 & 374 & 2104 & 0 & Z422 & 1 & 0 & 0 & 0 & 0 & 0 & 0 \\
\hline U145 & 0 & 951 & 0 & 0 & 3077 & 3629 & 2805 & Q41 & 0 & 1762 & 0 & 2546 & 0 & 0 & 3817 & $\mathrm{Z} 423$ & 0 & 0 & 0 & 1 & 0 & 1 & 0 \\
\hline U146 & 0 & 0 & 0 & 0 & 4374 & 1789 & 0 & Q42 & 3472 & 3165 & 3342 & 0 & 2349 & 0 & 0 & Z424 & 1 & 1 & 0 & 0 & 0 & 0 & 1 \\
\hline U147 & 1484 & 1035 & 0 & 0 & 0 & 4148 & 902 & Q43 & 0 & 0 & 0 & 4319 & 0 & 1104 & 1882 & Z425 & 1 & 1 & 0 & 0 & 0 & 0 & 0 \\
\hline U148 & 0 & 0 & 0 & 0 & 1309 & 0 & 0 & Q44 & 0 & 2891 & 0 & 3425 & 0 & 0 & 4360 & Z426 & 0 & 0 & 0 & 0 & 1 & 0 & 0 \\
\hline U211 & 0 & 416 & 0 & 0 & 0 & 0 & 640 & Q45 & 1357 & 1672 & 0 & 1765 & 0 & 0 & 669 & Z427 & 0 & 1 & 0 & 1 & 1 & 0 & 0 \\
\hline $\mathrm{U} 212$ & 0 & 0 & 0 & 166 & 0 & 80 & 1066 & Q46 & 58 & 0 & 448 & 1991 & 0 & 1061 & 0 & Z428 & 1 & 1 & 0 & 0 & 0 & 0 & 1 \\
\hline U213 & 0 & 488 & 0 & 1680 & 889 & 0 & 0 & Q47 & 0 & 3851 & 1740 & 2718 & 3295 & 1486 & 0 & Z431 & 1 & 1 & 0 & 1 & 0 & 1 & 0 \\
\hline U214 & 636 & 0 & 636 & 0 & 748 & 0 & 972 & $\hat{\mathrm{Q}} 48$ & 3099 & 1792 & 0 & 0 & 0 & 2953 & 2339 & Z432 & 0 & 0 & 0 & 0 & 0 & 1 & 0 \\
\hline U215 & 0 & 854 & 0 & 411 & 780 & 0 & 0 & Y11 & 0 & 1 & 1 & 0 & 1 & 1 & 1 & Z433 & 0 & 0 & 0 & 1 & 0 & 1 & 1 \\
\hline U216 & 0 & 809 & 0 & 363 & 0 & 0 & 0 & $\mathrm{Y} 12$ & 0 & 1 & 1 & 0 & 0 & 0 & 0 & Z434 & 0 & 0 & 0 & 1 & 0 & 0 & 0 \\
\hline U217 & 0 & 603 & 0 & 0 & 0 & 0 & 0 & Y13 & 1 & 1 & 0 & 0 & 0 & 1 & 1 & Z435 & 0 & 0 & 0 & 0 & 0 & 1 & 0 \\
\hline
\end{tabular}




\begin{tabular}{|c|c|c|c|c|c|c|c|c|c|c|c|c|c|c|c|c|c|c|c|c|c|c|c|}
\hline $\begin{array}{l}\text { Variable } \\
\text { Name }\end{array}$ & $\begin{array}{c}\text { Run } \\
\# 1\end{array}$ & $\begin{array}{c}\text { Run } \\
\# 2\end{array}$ & $\begin{array}{c}\text { Run } \\
\# 3\end{array}$ & $\begin{array}{c}\text { Run } \\
\# 4\end{array}$ & $\begin{array}{c}\text { Run } \\
\# 5\end{array}$ & $\begin{array}{c}\text { Run } \\
\# 6\end{array}$ & $\begin{array}{c}\text { Run } \\
\# 7\end{array}$ & $\begin{array}{c}\text { Variable } \\
\text { Name }\end{array}$ & $\begin{array}{c}\text { Run } \\
\# 1\end{array}$ & $\begin{array}{c}\text { Run } \\
\# 2\end{array}$ & $\begin{array}{c}\text { Run } \\
\# 3\end{array}$ & $\begin{array}{c}\text { Run } \\
\# 4\end{array}$ & $\begin{array}{c}\text { Run } \\
\# 5\end{array}$ & $\begin{array}{c}\text { Run } \\
\# 6\end{array}$ & $\begin{array}{c}\text { Run } \\
\# 7\end{array}$ & $\begin{array}{l}\text { Variable } \\
\text { Name }\end{array}$ & $\begin{array}{c}\text { Run } \\
\# 1\end{array}$ & $\begin{array}{c}\text { Run } \\
\# 2\end{array}$ & $\begin{array}{c}\text { Run } \\
\# 3\end{array}$ & $\begin{array}{c}\text { Run } \\
\# 4\end{array}$ & $\begin{array}{c}\text { Run } \\
\# 5\end{array}$ & $\begin{array}{c}\text { Run } \\
\# 6\end{array}$ & $\begin{array}{c}\text { Run } \\
\# 7\end{array}$ \\
\hline U218 & 0 & 0 & 0 & 0 & 0 & 0 & 0 & Y14 & 1 & 1 & 0 & 1 & 1 & 1 & 0 & Z436 & 0 & 1 & 1 & 1 & 1 & 0 & 0 \\
\hline U221 & 0 & 0 & 0 & 427 & 1604 & 991 & 0 & Y15 & 0 & 0 & 1 & 1 & 1 & 0 & 1 & Z437 & 1 & 1 & 0 & 1 & 0 & 0 & 1 \\
\hline U222 & 0 & 0 & 2227 & 887 & 0 & 0 & 0 & Y16 & 1 & 0 & 1 & 1 & 1 & 1 & 0 & Z438 & 1 & 0 & 0 & 1 & 1 & 0 & 1 \\
\hline U223 & 0 & 465 & 0 & 619 & 808 & 1321 & 477 & Y17 & 0 & 0 & 0 & 1 & 0 & 0 & 0 & Z441 & 0 & 0 & 0 & 0 & 1 & 0 & 0 \\
\hline U224 & 896 & 1810 & 909 & 288 & 0 & 0 & 0 & Y18 & 1 & 0 & 0 & 0 & 0 & 0 & 0 & Z442 & 0 & 0 & 1 & 1 & 0 & 0 & 0 \\
\hline U225 & 0 & 1662 & 0 & 1473 & 1452 & 0 & 0 & Y21 & 1 & 0 & 1 & 0 & 0 & 1 & 1 & Z443 & 1 & 0 & 1 & 1 & 1 & 0 & 0 \\
\hline U226 & 1535 & 0 & 0 & 1884 & 0 & 0 & 0 & Y22 & 1 & 1 & 0 & 0 & 0 & 1 & 0 & Z444 & 1 & 1 & 0 & 0 & 1 & 1 & 0 \\
\hline U227 & 0 & 0 & 0 & 0 & 0 & 0 & 0 & Y23 & 1 & 1 & 1 & 0 & 0 & 0 & 0 & Z445 & 1 & 0 & 1 & 1 & 1 & 1 & 1 \\
\hline U231 & 0 & 0 & 0 & 0 & 0 & 0 & 0 & Y25 & 0 & 1 & 1 & 0 & 0 & 1 & 0 & Z447 & 0 & 0 & 0 & 1 & 0 & 0 & 0 \\
\hline U232 & 895 & 524 & 0 & 2162 & 0 & 0 & 1204 & Y26 & 0 & 0 & 1 & 0 & 0 & 0 & 1 & Z448 & 1 & 1 & 0 & 0 & 1 & 0 & 0 \\
\hline U233 & 2160 & 0 & 0 & 1639 & 0 & 92 & 742 & Y27 & 0 & 0 & 0 & 0 & 1 & 1 & 1 & Z511 & 0 & 0 & 0 & 0 & 1 & 1 & 0 \\
\hline U234 & 1153 & 254 & 0 & 0 & 0 & 110 & 2162 & Y28 & 1 & 1 & 0 & 1 & 1 & 0 & 1 & Z512 & 0 & 0 & 0 & 0 & 0 & 1 & 1 \\
\hline U235 & 0 & 0 & 0 & 0 & 0 & 0 & 711 & Y31 & 0 & 0 & 1 & 1 & 0 & 0 & 1 & Z513 & 1 & 1 & 0 & 0 & 1 & 0 & 1 \\
\hline U236 & 0 & 0 & 0 & 0 & 886 & 0 & 0 & Y32 & 0 & 1 & 1 & 0 & 0 & 1 & 1 & Z514 & 1 & 1 & 1 & 0 & 1 & 1 & 0 \\
\hline U237 & 0 & 0 & 0 & 0 & 0 & 1726 & 0 & Y33 & 0 & 1 & 1 & 0 & 1 & 0 & 0 & Z515 & 1 & 0 & 1 & 1 & 0 & 1 & 0 \\
\hline U238 & 0 & 0 & 0 & 0 & 0 & 0 & 0 & Y34 & 1 & 1 & 0 & 0 & 1 & 1 & 0 & Z516 & 0 & 0 & 1 & 0 & 0 & 1 & 0 \\
\hline U241 & 0 & 3171 & 2165 & 1803 & 1294 & 2390 & 0 & Y35 & 1 & 1 & 0 & 1 & 0 & 1 & 1 & Z517 & 0 & 0 & 0 & 0 & 0 & 0 & 1 \\
\hline U242 & 0 & 0 & 0 & 0 & 0 & 1672 & 2607 & Y36 & 1 & 1 & 0 & 1 & 0 & 0 & 0 & Z518 & 1 & 0 & 0 & 0 & 0 & 1 & 0 \\
\hline U244 & 1522 & 0 & 307 & 239 & 0 & 2192 & 0 & Y38 & 0 & 0 & 1 & 0 & 1 & 1 & 0 & Z522 & 0 & 0 & 1 & 1 & 1 & 1 & 0 \\
\hline U245 & 2787 & 3624 & 3699 & 1706 & 0 & 0 & 0 & Y41 & 0 & 1 & 0 & 1 & 0 & 0 & 1 & Z523 & 0 & 1 & 1 & 1 & 0 & 0 & 0 \\
\hline U246 & 0 & 0 & 0 & 0 & 0 & 2657 & 932 & Y42 & 1 & 1 & 1 & 0 & 1 & 0 & 0 & Z524 & 0 & 0 & 0 & 0 & 1 & 1 & 0 \\
\hline U247 & 0 & 762 & 3989 & 2251 & 0 & 0 & 2680 & Y43 & 0 & 0 & 0 & 1 & 0 & 1 & 1 & Z525 & 1 & 0 & 0 & 0 & 0 & 0 & 1 \\
\hline U248 & 0 & 0 & 0 & 0 & 0 & 2468 & 0 & Y44 & 0 & 1 & 0 & 1 & 0 & 0 & 1 & Z526 & 0 & 1 & 0 & 1 & 0 & 0 & 1 \\
\hline U311 & 1202 & 0 & 0 & 839 & 0 & 0 & 0 & Y45 & 1 & 1 & 0 & 1 & 0 & 0 & 1 & Z527 & 1 & 0 & 1 & 0 & 0 & 1 & 0 \\
\hline U312 & 0 & 0 & 0 & 1153 & 0 & 0 & 0 & Y46 & 1 & 0 & 1 & 1 & 0 & 1 & 0 & Z528 & 0 & 0 & 1 & 1 & 0 & 1 & 0 \\
\hline U313 & 0 & 0 & 1119 & 0 & 0 & 1654 & 0 & Y47 & 0 & 1 & 1 & 1 & 1 & 1 & 0 & Z531 & 1 & 1 & 1 & 0 & 1 & 1 & 1 \\
\hline U314 & 0 & 0 & 0 & 836 & 0 & 0 & 0 & Y48 & 1 & 1 & 0 & 0 & 0 & 1 & 1 & Z532 & 0 & 1 & 1 & 0 & 1 & 0 & 0 \\
\hline U315 & 1243 & 0 & 682 & 0 & 0 & 967 & 495 & D1 & 1 & 2 & 3 & 0 & 0 & 0 & 3 & Z533 & 0 & 0 & 0 & 0 & 1 & 1 & 0 \\
\hline U316 & 732 & 0 & 0 & 0 & 0 & 0 & 850 & D2 & 2 & 3 & 2 & 1 & 0 & 3 & 3 & Z534 & 0 & 0 & 0 & 1 & 1 & 1 & 0 \\
\hline U317 & 0 & 0 & 0 & 115 & 0 & 0 & 0 & D3 & 2 & 0 & 3 & 2 & 4 & 0 & 3 & Z535 & 1 & 1 & 0 & 0 & 1 & 1 & 0 \\
\hline U318 & 0 & 955 & 0 & 0 & 960 & 0 & 0 & D4 & 3 & 4 & 1 & 2 & 2 & 5 & 0 & Z536 & 1 & 0 & 1 & 0 & 1 & 1 & 0 \\
\hline U321 & 0 & 2660 & 0 & 0 & 1154 & 0 & 693 & D5 & 0 & 2 & 1 & 3 & 4 & 0 & 2 & Z537 & 0 & 1 & 1 & 0 & 0 & 0 & 1 \\
\hline U322 & 0 & 0 & 0 & 0 & 1905 & 0 & 1598 & D6 & 0 & 0 & 0 & 0 & 0 & 0 & 0 & Z538 & 1 & 0 & 0 & 0 & 0 & 0 & 1 \\
\hline U323 & 0 & 0 & 0 & 0 & 1772 & 0 & 2103 & D7 & 0 & 0 & 0 & 0 & 0 & 0 & 0 & Z541 & 1 & 1 & 0 & 1 & 0 & 1 & 1 \\
\hline U324 & 0 & 0 & 0 & 244 & 0 & 358 & 0 & D8 & 0 & 0 & 0 & 0 & 0 & 0 & 0 & Z542 & 1 & 0 & 1 & 1 & 0 & 1 & 0 \\
\hline U325 & 1142 & 0 & 0 & 0 & 0 & 2371 & 2497 & D9 & 0 & 0 & 0 & 0 & 0 & 0 & 0 & Z543 & 0 & 1 & 1 & 0 & 1 & 0 & 0 \\
\hline U326 & 0 & 0 & 0 & 0 & 1301 & 2909 & 0 & D10 & 0 & 0 & 0 & 0 & 0 & 1 & 0 & Z544 & 0 & 0 & 0 & 0 & 1 & 1 & 0 \\
\hline U327 & 0 & 0 & 1133 & 0 & 0 & 0 & 0 & Z111 & 0 & 1 & 0 & 0 & 0 & 1 & 0 & Z545 & 0 & 0 & 1 & 0 & 1 & 0 & 1 \\
\hline U328 & 0 & 0 & 0 & 0 & 0 & 0 & 300 & Z112 & 1 & 0 & 0 & 0 & 1 & 1 & 0 & Z546 & 1 & 1 & 0 & 0 & 0 & 1 & 1 \\
\hline
\end{tabular}




\begin{tabular}{|c|c|c|c|c|c|c|c|c|c|c|c|c|c|c|c|c|c|c|c|c|c|c|c|}
\hline $\begin{array}{c}\text { Variable } \\
\text { Name }\end{array}$ & $\begin{array}{c}\text { Run } \\
\# 1\end{array}$ & $\begin{array}{c}\text { Run } \\
\# 2\end{array}$ & $\begin{array}{c}\text { Run } \\
\# 3\end{array}$ & $\begin{array}{c}\text { Run } \\
\# 4\end{array}$ & $\begin{array}{c}\text { Run } \\
\# 5\end{array}$ & $\begin{array}{c}\text { Run } \\
\# 6\end{array}$ & $\begin{array}{c}\text { Run } \\
\# 7\end{array}$ & $\begin{array}{c}\text { Variable } \\
\text { Name }\end{array}$ & $\begin{array}{c}\text { Run } \\
\# 1\end{array}$ & $\begin{array}{c}\text { Run } \\
\# 2\end{array}$ & $\begin{array}{c}\text { Run } \\
\# 3\end{array}$ & $\begin{array}{c}\text { Run } \\
\# 4\end{array}$ & $\begin{array}{c}\text { Run } \\
\# 5\end{array}$ & $\begin{array}{c}\text { Run } \\
\# 6\end{array}$ & $\begin{array}{c}\text { Run } \\
\# 7\end{array}$ & $\begin{array}{c}\text { Variable } \\
\text { Name }\end{array}$ & $\begin{array}{c}\text { Run } \\
\# 1\end{array}$ & $\begin{array}{c}\text { Run } \\
\# 2\end{array}$ & $\begin{array}{c}\text { Run } \\
\# 3\end{array}$ & $\begin{array}{c}\text { Run } \\
\# 4\end{array}$ & $\begin{array}{c}\text { Run } \\
\# 5\end{array}$ & $\begin{array}{c}\text { Run } \\
\# 6\end{array}$ & $\begin{array}{c}\text { Run } \\
\# 7\end{array}$ \\
\hline U331 & 0 & 677 & 0 & 0 & 591 & 1788 & 0 & Z113 & 0 & 0 & 0 & 0 & 0 & 0 & 0 & Z547 & 1 & 0 & 0 & 0 & 1 & 0 & 1 \\
\hline U332 & 1270 & 0 & 445 & 0 & 0 & 0 & 0 & Z114 & 0 & 0 & 1 & 0 & 0 & 1 & 1 & Z548 & 0 & 0 & 1 & 1 & 1 & 0 & 1 \\
\hline U333 & 0 & 1629 & 0 & 0 & 1129 & 1572 & 0 & Z115 & 0 & 1 & 0 & 0 & 0 & 0 & 1 & I11 & 0 & 0 & 0 & 0 & 0 & 0 & 0 \\
\hline U334 & 0 & 0 & 2170 & 0 & 0 & 0 & 0 & Z116 & 0 & 1 & 0 & 1 & 0 & 0 & 1 & $\mathrm{I} 12$ & 0 & 0 & 0 & 0 & 0 & 0 & 0 \\
\hline U335 & 0 & 0 & 251 & 557 & 1011 & 0 & 0 & Z117 & 1 & 1 & 1 & 0 & 1 & 1 & 0 & $\mathrm{I} 13$ & 0 & 0 & 0 & 0 & 0 & 0 & 0 \\
\hline U336 & 0 & 253 & 0 & 0 & 0 & 0 & 1603 & Z118 & 0 & 0 & 1 & 1 & 0 & 1 & 1 & I14 & 0 & 0 & 0 & 0 & 0 & 0 & 0 \\
\hline U337 & 562 & 385 & 0 & 130 & 2161 & 0 & 0 & Z121 & 0 & 1 & 0 & 1 & 0 & 0 & 0 & I15 & 0 & 0 & 0 & 0 & 0 & 0 & 0 \\
\hline U338 & 0 & 2160 & 0 & 0 & 0 & 0 & 0 & Z122 & 1 & 0 & 1 & 0 & 0 & 0 & 1 & I16 & 0 & 0 & 0 & 0 & 0 & 0 & 0 \\
\hline U342 & 2075 & 1043 & 0 & 1191 & 0 & 0 & 0 & Z124 & 0 & 0 & 0 & 1 & 0 & 0 & 1 & I18 & 0 & 0 & 0 & 0 & 0 & 0 & 0 \\
\hline U343 & 0 & 1915 & 1148 & 0 & 0 & 3650 & 730 & Z125 & 0 & 0 & 0 & 1 & 1 & 0 & 0 & $\mathrm{I} 21$ & 0 & 0 & 0 & 0 & 0 & 0 & 0 \\
\hline U344 & 0 & 1924 & 3859 & 2939 & 2241 & 0 & 2241 & Z126 & 1 & 0 & 1 & 0 & 0 & 0 & 0 & $\mathrm{I} 22$ & 0 & 0 & 0 & 0 & 0 & 0 & 0 \\
\hline U345 & 0 & 0 & 0 & 2008 & 0 & 0 & 0 & Z127 & 1 & 1 & 0 & 0 & 0 & 0 & 1 & $\mathrm{I} 23$ & 0 & 0 & 0 & 0 & 0 & 0 & 0 \\
\hline U346 & 1918 & 0 & 3165 & 2841 & 0 & 0 & 0 & Z128 & 0 & 0 & 1 & 1 & 0 & 0 & 0 & I 24 & 0 & 0 & 0 & 0 & 0 & 0 & 0 \\
\hline U347 & 0 & 0 & 0 & 320 & 0 & 0 & 0 & Z131 & 0 & 0 & 0 & 0 & 1 & 0 & 0 & I 25 & 0 & 0 & 0 & 0 & 0 & 0 & 0 \\
\hline U348 & 1396 & 1122 & 2335 & 1628 & 1099 & 0 & 0 & Z132 & 0 & 1 & 1 & 0 & 1 & 0 & 0 & I26 & 0 & 0 & 0 & 0 & 0 & 0 & 0 \\
\hline U411 & 0 & 0 & 738 & 361 & 0 & 0 & 0 & Z133 & 0 & 0 & 0 & 0 & 0 & 0 & 0 & I27 & 0 & 0 & 0 & 0 & 0 & 0 & 0 \\
\hline U412 & 413 & 0 & 261 & 0 & 0 & 0 & 124 & Z134 & 0 & 1 & 0 & 0 & 1 & 1 & 0 & $\mathrm{I} 28$ & 0 & 0 & 0 & 0 & 0 & 0 & 0 \\
\hline U413 & 0 & 444 & 561 & 0 & 212 & 0 & 212 & Z135 & 1 & 1 & 1 & 1 & 0 & 0 & 0 & I31 & 0 & 0 & 0 & 0 & 0 & 0 & 0 \\
\hline U415 & 0 & 0 & 245 & 467 & 598 & 0 & 0 & Z137 & 1 & 0 & 0 & 1 & 0 & 0 & 0 & $\mathrm{I} 33$ & 0 & 0 & 0 & 0 & 0 & 0 & 0 \\
\hline U416 & 0 & 9 & 0 & 0 & 0 & 215 & 0 & Z138 & 0 & 0 & 1 & 1 & 1 & 1 & 0 & $\mathrm{I} 34$ & 0 & 0 & 0 & 0 & 0 & 0 & 0 \\
\hline U417 & 309 & 0 & 0 & 0 & 0 & 226 & 409 & Z141 & 0 & 0 & 0 & 0 & 1 & 1 & 1 & I35 & 0 & 0 & 0 & 0 & 0 & 0 & 0 \\
\hline U418 & 182 & 0 & 0 & 0 & 0 & 0 & 0 & Z142 & 0 & 1 & 0 & 0 & 1 & 0 & 1 & I36 & 0 & 0 & 0 & 0 & 0 & 0 & 0 \\
\hline U421 & 1537 & 0 & 0 & 0 & 0 & 0 & 0 & Z143 & 1 & 1 & 1 & 1 & 1 & 0 & 1 & I37 & 0 & 0 & 0 & 0 & 0 & 0 & 0 \\
\hline U422 & 631 & 0 & 0 & 0 & 0 & 0 & 0 & Z144 & 1 & 1 & 1 & 0 & 1 & 1 & 0 & I38 & 0 & 0 & 0 & 0 & 0 & 0 & 0 \\
\hline U423 & 0 & 0 & 0 & 636 & 0 & 1262 & 0 & Z145 & 0 & 1 & 0 & 0 & 1 & 1 & 1 & I41 & 0 & 0 & 0 & 0 & 0 & 0 & 0 \\
\hline U424 & 1624 & 710 & 0 & 0 & 0 & 0 & 306 & Z146 & 0 & 0 & 0 & 0 & 1 & 1 & 0 & I 42 & 0 & 0 & 0 & 0 & 0 & 0 & 0 \\
\hline U425 & 989 & 650 & 0 & 0 & 0 & 0 & 0 & Z147 & 1 & 1 & 0 & 0 & 0 & 1 & 1 & I43 & 0 & 0 & 0 & 0 & 0 & 0 & 0 \\
\hline U426 & 0 & 0 & 0 & 0 & 1578 & 0 & 0 & Z148 & 0 & 0 & 0 & 0 & 1 & 0 & 0 & I 44 & 0 & 0 & 0 & 0 & 0 & 0 & 0 \\
\hline U427 & 0 & 1104 & 0 & 2335 & 713 & 0 & 0 & Z211 & 0 & 1 & 0 & 0 & 0 & 0 & 1 & I45 & 0 & 0 & 0 & 0 & 0 & 0 & 0 \\
\hline $\mathrm{U} 428$ & 849 & 872 & 0 & 0 & 0 & 0 & 816 & Z212 & 0 & 0 & 0 & 1 & 0 & 1 & 1 & I 46 & 0 & 0 & 0 & 0 & 0 & 0 & 0 \\
\hline U431 & 1350 & 865 & 0 & 1738 & 0 & 241 & 0 & Z213 & 0 & 1 & 0 & 1 & 1 & 0 & 0 & I 47 & 0 & 0 & 0 & 0 & 0 & 0 & 0 \\
\hline U432 & 0 & 0 & 0 & 0 & 0 & 1197 & 0 & Z214 & 1 & 0 & 1 & 0 & 1 & 0 & 1 & I 48 & 0 & 0 & 0 & 0 & 0 & 0 & 0 \\
\hline U433 & 0 & 0 & 0 & 520 & 0 & 188 & 1415 & Z215 & 0 & 1 & 0 & 1 & 1 & 0 & 0 & G11 & 0 & 1 & 1 & 1 & 1 & 0 & 1 \\
\hline U434 & 0 & 0 & 0 & 1625 & 0 & 0 & 0 & Z216 & 0 & 1 & 0 & 1 & 0 & 0 & 0 & G12 & 1 & 1 & 1 & 0 & 1 & 1 & 1 \\
\hline U435 & 0 & 0 & 0 & 0 & 0 & 1621 & 0 & Z217 & 0 & 1 & 0 & 0 & 0 & 0 & 0 & G13 & 1 & 0 & 1 & 1 & 1 & 1 & 0 \\
\hline U436 & 0 & 1446 & 1314 & 1030 & 680 & 0 & 0 & Z218 & 0 & 0 & 0 & 0 & 0 & 0 & 0 & G14 & 0 & 0 & 0 & 1 & 1 & 0 & 0 \\
\hline U437 & 1227 & 509 & 0 & 248 & 0 & 0 & 762 & Z221 & 0 & 0 & 0 & 1 & 1 & 1 & 0 & G15 & 1 & 1 & 0 & 0 & 0 & 1 & 1 \\
\hline U438 & 1014 & 0 & 0 & 140 & 761 & 0 & 455 & Z222 & 0 & 0 & 1 & 1 & 0 & 0 & 0 & G16 & 0 & 0 & 0 & 1 & 1 & 1 & 0 \\
\hline
\end{tabular}




\begin{tabular}{|c|c|c|c|c|c|c|c|c|c|c|c|c|c|c|c|c|c|c|c|c|c|c|c|}
\hline $\begin{array}{l}\text { Variable } \\
\text { Name }\end{array}$ & $\begin{array}{c}\text { Run } \\
\# 1\end{array}$ & $\begin{array}{c}\text { Run } \\
\# 2\end{array}$ & $\begin{array}{c}\text { Run } \\
\# 3\end{array}$ & $\begin{array}{c}\text { Run } \\
\# 4\end{array}$ & $\begin{array}{c}\text { Run } \\
\# 5\end{array}$ & $\begin{array}{c}\text { Run } \\
\# 6\end{array}$ & $\begin{array}{c}\text { Run } \\
\# 7\end{array}$ & $\begin{array}{c}\text { Variable } \\
\text { Name }\end{array}$ & $\begin{array}{c}\text { Run } \\
\# 1\end{array}$ & $\begin{array}{c}\text { Run } \\
\# 2\end{array}$ & $\begin{array}{c}\text { Run } \\
\# 3\end{array}$ & $\begin{array}{c}\text { Run } \\
\# 4\end{array}$ & $\begin{array}{c}\text { Run } \\
\# 5\end{array}$ & $\begin{array}{c}\text { Run } \\
\# 6\end{array}$ & $\begin{array}{c}\text { Run } \\
\# 7\end{array}$ & $\begin{array}{c}\text { Variable } \\
\text { Name }\end{array}$ & $\begin{array}{c}\text { Run } \\
\# 1\end{array}$ & $\begin{array}{c}\text { Run } \\
\# 2\end{array}$ & $\begin{array}{c}\text { Run } \\
\# 3\end{array}$ & $\begin{array}{c}\text { Run } \\
\# 4\end{array}$ & $\begin{array}{c}\text { Run } \\
\# 5\end{array}$ & $\begin{array}{c}\text { Run } \\
\# 6\end{array}$ & $\begin{array}{c}\text { Run } \\
\# 7\end{array}$ \\
\hline U441 & 0 & 0 & 0 & 0 & 2054 & 0 & 0 & Z223 & 0 & 1 & 0 & 1 & 1 & 1 & 1 & G17 & 1 & 0 & 0 & 1 & 0 & 1 & 0 \\
\hline U442 & 0 & 0 & 1514 & 620 & 0 & 0 & 0 & Z224 & 1 & 1 & 1 & 1 & 0 & 0 & 0 & G18 & 1 & 1 & 0 & 1 & 1 & 1 & 0 \\
\hline U443 & 1080 & 0 & 1744 & 685 & 1645 & 0 & 0 & Z225 & 0 & 1 & 0 & 1 & 1 & 0 & 0 & G21 & 0 & 1 & 1 & 1 & 0 & 1 & 0 \\
\hline U444 & 770 & 135 & 0 & 0 & 1282 & 1456 & 0 & Z226 & 1 & 0 & 0 & 1 & 0 & 0 & 0 & G22 & 1 & 0 & 0 & 1 & 1 & 0 & 1 \\
\hline U445 & 2097 & 0 & 1673 & 763 & 1964 & 2610 & 757 & Z227 & 0 & 0 & 0 & 0 & 0 & 0 & 0 & G23 & 1 & 0 & 0 & 1 & 1 & 0 & 1 \\
\hline U446 & 0 & 1952 & 2389 & 1168 & 1633 & 0 & 1224 & Z228 & 1 & 0 & 1 & 1 & 1 & 1 & 0 & G24 & 0 & 0 & 1 & 0 & 0 & 1 & 0 \\
\hline U447 & 0 & 0 & 0 & 351 & 0 & 0 & 0 & Z231 & 0 & 0 & 0 & 0 & 0 & 0 & 0 & G25 & 1 & 0 & 0 & 1 & 1 & 0 & 0 \\
\hline U448 & 914 & 2476 & 0 & 0 & 2467 & 0 & 0 & Z232 & 1 & 1 & 0 & 1 & 0 & 0 & 1 & G26 & 1 & 0 & 1 & 0 & 1 & 1 & 0 \\
\hline U512 & 0 & 0 & 0 & 0 & 0 & 1070 & 131 & Z234 & 1 & 1 & 0 & 0 & 0 & 1 & 1 & G28 & 0 & 1 & 1 & 1 & 1 & 0 & 0 \\
\hline U513 & 460 & 271 & 0 & 0 & 579 & 0 & 549 & Z235 & 0 & 0 & 0 & 0 & 0 & 0 & 1 & G31 & 1 & 1 & 0 & 1 & 0 & 1 & 0 \\
\hline U514 & 1064 & 1481 & 1067 & 0 & 1194 & 877 & 0 & Z236 & 0 & 0 & 0 & 0 & 1 & 0 & 0 & G32 & 0 & 0 & 0 & 1 & 0 & 0 & 1 \\
\hline U515 & 798 & 0 & 825 & 356 & 0 & 1073 & 0 & Z237 & 0 & 0 & 0 & 0 & 0 & 1 & 0 & G33 & 0 & 1 & 1 & 1 & 1 & 1 & 1 \\
\hline U516 & 0 & 0 & 924 & 0 & 0 & 967 & 0 & Z238 & 0 & 0 & 0 & 0 & 0 & 0 & 0 & G34 & 1 & 1 & 0 & 1 & 0 & 0 & 1 \\
\hline U517 & 0 & 0 & 0 & 0 & 0 & 0 & 671 & Z241 & 0 & 1 & 1 & 1 & 1 & 1 & 0 & G35 & 0 & 0 & 0 & 0 & 0 & 1 & 0 \\
\hline U518 & 435 & 0 & 0 & 0 & 0 & 393 & 0 & Z242 & 0 & 0 & 0 & 0 & 0 & 1 & 1 & G36 & 1 & 1 & 0 & 0 & 0 & 1 & 0 \\
\hline U521 & 0 & 0 & 2431 & 0 & 0 & 0 & 0 & Z243 & 1 & 1 & 0 & 0 & 0 & 1 & 0 & G37 & 1 & 1 & 1 & 0 & 1 & 1 & 0 \\
\hline U522 & 0 & 0 & 272 & 1753 & 743 & 1458 & 0 & Z244 & 1 & 0 & 1 & 1 & 0 & 1 & 0 & G38 & 0 & 1 & 1 & 0 & 0 & 1 & 0 \\
\hline U523 & 0 & 1279 & 1052 & 1252 & 0 & 0 & 0 & Z245 & 1 & 1 & 1 & 1 & 0 & 0 & 0 & G41 & 1 & 1 & 1 & 0 & 0 & 0 & 1 \\
\hline U525 & 631 & 0 & 0 & 0 & 0 & 0 & 267 & Z247 & 0 & 1 & 1 & 1 & 0 & 0 & 1 & G43 & 0 & 0 & 1 & 1 & 1 & 0 & 0 \\
\hline U526 & 0 & 2879 & 0 & 1000 & 0 & 0 & 1556 & Z248 & 0 & 0 & 0 & 0 & 0 & 1 & 0 & G44 & 0 & 0 & 1 & 0 & 0 & 0 & 1 \\
\hline U527 & 1912 & 0 & 1504 & 0 & 0 & 2389 & 0 & Z311 & 1 & 0 & 0 & 1 & 0 & 0 & 0 & G45 & 1 & 0 & 0 & 1 & 0 & 0 & 1 \\
\hline U528 & 0 & 0 & 169 & 156 & 0 & 1386 & 0 & Z312 & 0 & 0 & 0 & 1 & 0 & 0 & 0 & G46 & 0 & 1 & 1 & 1 & 1 & 0 & 1 \\
\hline U531 & 808 & 619 & 975 & 0 & 1098 & 135 & 1392 & Z313 & 0 & 0 & 1 & 0 & 0 & 1 & 0 & G47 & 0 & 0 & 0 & 0 & 1 & 0 & 1 \\
\hline U532 & 0 & 250 & 1765 & 0 & 1210 & 0 & 0 & Z314 & 0 & 0 & 0 & 1 & 0 & 0 & 0 & G48 & 1 & 0 & 0 & 0 & 1 & 0 & 1 \\
\hline U533 & 0 & 0 & 0 & 0 & 715 & 307 & 0 & Z315 & 1 & 0 & 1 & 0 & 0 & 1 & 1 & G51 & 1 & 0 & 1 & 1 & 1 & 1 & 1 \\
\hline U534 & 0 & 0 & 0 & 533 & 283 & 385 & 0 & Z316 & 1 & 0 & 0 & 0 & 0 & 0 & 1 & G52 & 1 & 0 & 0 & 0 & 0 & 0 & 0 \\
\hline U535 & 329 & 547 & 0 & 0 & 1151 & 153 & 0 & Z317 & 0 & 0 & 0 & 1 & 0 & 0 & 0 & G53 & 0 & 0 & 0 & 0 & 0 & 1 & 0 \\
\hline U536 & 91 & 0 & 402 & 0 & 593 & 1347 & 0 & Z318 & 0 & 1 & 0 & 0 & 1 & 0 & 0 & G54 & 1 & 0 & 1 & 1 & 1 & 1 & 0 \\
\hline U537 & 0 & 1270 & 1550 & 0 & 0 & 0 & 1397 & Z321 & 0 & 1 & 0 & 0 & 1 & 0 & 1 & G55 & 1 & 1 & 1 & 0 & 0 & 1 & 1 \\
\hline U538 & 1151 & 0 & 0 & 0 & 0 & 0 & 1705 & Z322 & 0 & 0 & 0 & 0 & 1 & 0 & 1 & G56 & 1 & 1 & 0 & 0 & 0 & 1 & 1 \\
\hline U541 & 2332 & 811 & 0 & 318 & 0 & 373 & 1499 & Z323 & 0 & 0 & 0 & 0 & 1 & 0 & 1 & G57 & 0 & 1 & 1 & 1 & 0 & 1 & 1 \\
\hline U542 & 462 & 0 & 1152 & 4189 & 0 & 4333 & 0 & Z324 & 0 & 0 & 0 & 1 & 0 & 1 & 0 & G58 & 1 & 1 & 1 & 0 & 0 & 1 & 0 \\
\hline U543 & 0 & 1116 & 251 & 0 & 2200 & 0 & 0 & Z325 & 1 & 0 & 0 & 0 & 0 & 1 & 1 & & & & & & & & \\
\hline U544 & 0 & 0 & 0 & 0 & 1428 & 2568 & 0 & Z326 & 0 & 0 & 0 & 0 & 1 & 1 & 0 & & & & & & & & \\
\hline
\end{tabular}




\section{References}

1. Chu, P.Y.; Chang, K.H.; Huang, H.F. How to increase supplier flexibility through social mechanisms and influence strategies? J. Bus. Ind. Mark. 2012, 27, 115-131. [CrossRef]

2. Deng, W.; Feng, L.; Zhao, X.; Lou, Y. Effects of supply chain competition on firms' product sustainability strategy. J. Clean. Prod. 2020, 275, 124061. [CrossRef]

3. Ramanathan, U.; Ramanathan, R. Supply Chain Strategies, Issues and Models; Springer: Cham, Switzerland, 2014.

4. Mosallanezhad, B.; Hajiaghaei-Keshteli, M.; Triki, C. Shrimp closed-loop supply chain network design. Soft Comput. 2021, 25, 7399-7422. [CrossRef]

5. Borda, A.; Morales, O.; Teegen, H.; Rees, G.; Gonzalez-Perez, M.A. Addressing Sustainable Rural Development with Shared Value: A Peruvian Model from the Cacao Industry. Sustainability 2021, 13, 8028. [CrossRef]

6. Kim, S.-S.; Baek, W.-Y.; Byon, K.K.; Ju, S.-B. Creating Shared Value to Enhance Customer Loyalty: A Case of a Sporting Goods Company in Korean Athletic Shoe Market. Sustainability 2021, 13, 7031. [CrossRef]

7. Salehi-Amiri, A.; Zahedi, A.; Hajiaghaei-Keshteli, M.; Akbapour, N. Designing a sustainable closed-loop supply chain network for walnut industry. Renew. Sustain. Energy Rev. 2021, 141, 110821. [CrossRef]

8. Tliche, Y.; Taghipour, A.; Canel-Depitre, B. An improved forecasting approach to reduce inventory levels in decentralized supply chains. Eur. J. Oper. Res. 2020, 287, 511-527. [CrossRef]

9. Tsai, Y.L.; Yang, Y.J.; Lin, C.-H. A dynamic decision approach for supplier selection using ant colony system. Expert Syst. Appl. 2010, 37, 8313-8321. [CrossRef]

10. Rezaei, J.; Ortt, R. A multi-variable approach to supplier segmentation. Int. J. Prod. Res. 2012, 50, 4593-4611. [CrossRef]

11. Rezaei, J.; Wang, J.; Tavasszy, L. Linking supplier development to supplier segmentation using Best Worst Method. Expert Syst. Appl. 2015, 42, 9152-9164. [CrossRef]

12. Senyigit, E. The optimization of lot sizing with supplier selection problem in multi-echelon defective supply chain network. Math. Comput. Model. Dyn. Syst. 2012, 18, 273-286. [CrossRef]

13. Klasa, K.; Greer, S.L.; van Ginneken, E. Strategic Purchasing in Practice: Comparing Ten European Countries. Health Policy 2018, 122, 457-472. [CrossRef] [PubMed]

14. Park, J.; Shin, K.; Chang, T.W.; Park, J. An integrative framework for supplier relationship management. Ind. Manag. Data Syst. 2010, 110, 495-515. [CrossRef]

15. Heiskanen, A.; Newman, M.; Eklin, M. Control, trust, power, and the dynamics of information system outsourcing relationships: A process study of contractual software development. J. Strat. Inf. Syst. 2008, 17, 268-286. [CrossRef]

16. Gold, S.; Awasthi, A. Sustainable global supplier selection extended towards sustainability risks from $(1+n)$ th tier suppliers using fuzzy AHP based approach. IFAC-PapersOnLine 2015, 48, 966-971. [CrossRef]

17. Lopes, A.P.; Rodriguez-Lopez, N. A Decision Support Tool for Supplier Evaluation and Selection. Sustainability 2021, $13,12387$. [CrossRef]

18. Kakabadse, A. Smart Sourcing: International Best Practice; Springer: Cham, Switzerland, 2001.

19. Khazaei, M.; Ramezani, M.; Padash, A.; DeTombe, D. Creating shared value to redesigning IT-service products using SYRCS; Diagnosing and tackling complex problems. Inf. Syst. e-Bus. Manag. 2021, 19, 957-992. [CrossRef]

20. Vosooghidizaji, M.; Taghipour, A.; Canel-Depitre, B. Supply chain coordination under information asymmetry: A review. Int. J. Prod. Res. 2020, 58, 1805-1834. [CrossRef]

21. Yawar, S.A.; Seuring, S. Reviewing and conceptualizing supplier development. Benchmarking Int. J. 2020, 27, 2565-2598. [CrossRef]

22. Khazaei, M.; Ramezani, M.; Padash, A.; DeTombe, D. The quantification role of BWM in problem structuring methods: SYRCS methodology. In Proceedings of the International Workshop on Best-Worst Method, Delft, The Netherlands, 10-11 June 2021; Springer: Cham, Switzerland, 2021; pp. 252-271.

23. Porter, M.E.; Hills, G.; Pfitzer, M.; Patscheke, S.; Hawkins, E. Measuring Shared Value: How to Unlock Value by Linking Social and Business Results; Foundation Strategy Group: Boston, MA, USA, 2011.

24. Lichtenthaler, U. Shared Value Innovation: Linking Competitiveness and Societal Goals in the Context of Digital Transformation. Int. J. Innov. Technol. Manag. 2017, 14, 1750018. [CrossRef]

25. Von Liel, B. Creating Shared Value as Future Factor of Competition: Analysis and Empirical Evidence; Springer: Cham, Switzerland, 2016.

26. Font, X.; Guix, M.; Bonilla-Priego, M.J. Corporate social responsibility in cruising: Using materiality analysis to create shared value. Tour. Manag. 2016, 53, 175-186. [CrossRef]

27. Wieland, J. Creating Shared Value_Concepts, Experience, Criticism; Springer: Cham, Switzerland, 2017.

28. Porter, M.E.; Kramer, M.R. The link between competitive advantage and corporate social responsibility. Harv. Bus. Rev. 2006, 84, 78-92. [PubMed]

29. Porter, M.E.; Kramer, M.R. Creating shared value. In Managing Sustainable Business; Springer: Cham, Switzerland, 2019; pp. 323-346.

30. Taghipour, A.; Hoang, P.; Cao, X. Just in Time/Lean Purchasing Approach: An Investigation for Research and Applications. J. Adv. Manag. Sci. 2020, 8, 43-48. [CrossRef]

31. Goodarzian, F.; Wamba, S.F.; Mathiyazhagan, K.; Taghipour, A. A new bi-objective green medicine supply chain network design under fuzzy environment: Hybrid metaheuristic algorithms. Comput. Ind. Eng. 2021, 160, 107535. [CrossRef]

32. Litow, S.S. The Challenge for Business and Society; John Wiley \& Sons, Inc.: Hoboken, NJ, USA, 2018. 
33. Beschorner, T. Creating Shared Value: The One-Trick Pony Approach. Bus. Ethics J. Rev. 2014, 1, 106-112. [CrossRef]

34. Alberti, F.G.; Belfanti, F. Creating shared value and clusters. Compet. Rev. Int. Bus. J. 2019, 29, 39-60. [CrossRef]

35. Mendy, J. Supporting the creation of shared value. Strat. Chang. 2019, 28, 157-161. [CrossRef]

36. Lenssen, G.G.; Smith, N.C. Managing Sustainable Business; Springer: Cham, Switzerland, 2019.

37. Blakely, E.J.; Leigh, N.G. Planning Local Economic Development; SAGE: New York, NY, USA, 2013.

38. Jose, P. Business and society: Creating shared value: In conversation with NR Narayana Murthy, Founder, Infosys. IIMB Manag. Rev. 2016, 28, 43-51.

39. Lee, D.J.; Moon, J.; Cho, J.; Kang, H.-G.; Jeong, J. From corporate social responsibility to creating shared value with suppliers through mutual firm foundation in the Korean bakery industry: A case study of the SPC Group. Asia Pac. Bus. Rev. 2014, 20, 461-483. [CrossRef]

40. Duan, Z.; Guo, P.; Li, W.; Yu, M.; Zhang, H.; Zou, J.; Zorn, M. Road to Transparency: Relationship to Risks and How It Is Perceived and Handled by Chinese Extractive Companies Involved in Overseas Investment. J. Int. Bus. Ethics 2015, 8, 44-65.

41. Andelin, M.; Karhu, J.; Junnila, S. Creating shared value in a construction project-A case study. Procedia Econ. Financ. 2015, 21, 446-453. [CrossRef]

42. Moon, H.-C.; Parc, J.; Yim, S.H.; Park, N. An extension of Porter and Kramer's creating shared value (CSV): Reorienting strategies and seeking international cooperation. J. Int. Area Stud. 2011, 18, 49-64.

43. Laudal, T. Measuring shared value in multinational corporations. Soc. Responsib. J. 2018, 14, 917-933. [CrossRef]

44. Dehghan Nayeri, M.; Khazaei, M.; Alinasab-Imani, F. The Critical Heuristics of Iranian Banking Credit System: Analysis of the Antithetical Opinions of the Beneficiaries. Syst. Pract. 2020, 33, 363-392. [CrossRef]

45. Ramezani, M.; Azar, A.; Khazaei, M. Gap analysis through a hybrid method: Critical systems heuristics and best worst method. In Proceedings of the International Workshop on Best-Worst Method, Delft, The Netherlands, 10-11 June 2021; Springer: Cham, Switzerland, 2021; pp. 272-286.

46. Sinclair, S.; Rockwell, G. Teaching computer-assisted text analysis: Approaches to learning new methodologies. In Digital Humanities Pedagogy: Practices, Principles, and Politics; Open Book Publishers: Cambridge, UK, 2012; pp. $241-263$.

47. Welsh, M.E. Review of Voyant tools. Collab. Librariansh. 2014, 6, 96-98.

48. Zhang, M.; Pawar, K.S.; Bhardwaj, S. Improving supply chain social responsibility through supplier development. Prod. Plan. Control 2017, 28, 500-511. [CrossRef]

49. Xu, L.; Shi, X.; Xie, Y.; Tsai, S.-B. Corporate social responsibility-based supplier selection process in sustainable supply chains. In Green Production Strategies for Sustainability; IGI Global: Hershey, PA, USA, 2018; pp. 54-71.

50. Chen, Y.; Wang, S.; Yao, J.; Li, Y.; Yang, S. Socially responsible supplier selection and sustainable supply chain development: A combined approach of total interpretive structural modeling and fuzzy analytic network process. Bus. Strat. Environ. 2018, 27, 1708-1719. [CrossRef]

51. Yadlapalli, A.; Rahman, S.; Gunasekaran, A. Socially responsible governance mechanisms for manufacturing firms in apparel supply chains. Int. J. Prod. Econ. 2018, 196, 135-149. [CrossRef]

52. Govindan, K.; Shankar, M.; Kannan, D. Supplier selection based on corporate social responsibility practices. Int. J. Prod. Econ. 2018, 200, 353-379. [CrossRef]

53. Mani, V.; Gunasekaran, A.; Delgado, C. Enhancing supply chain performance through supplier social sustainability: An emerging economy perspective. Int. J. Prod. Econ. 2018, 195, 259-272. [CrossRef]

54. Girdwichai, L.; Sriviboon, C. Is Supplier Social Sustainability Vital for Supplier's Financial and Social Performance? Analyzing Mediating Role of Firm Reputation in Thailand. Int. J. Supply Chain Manag. 2019, 8, 369-379.

55. Yaghin, R.G.; Sarlak, P. Joint order allocation and transportation planning under uncertainty within a socially responsible supply chain. J. Model. Manag. 2019, 15, 531-565. [CrossRef]

56. Fontana, E.; Egels-Zandén, N. Non Sibi, Sed Omnibus: Influence of Supplier Collective Behaviour on Corporate Social Responsibility in the Bangladeshi Apparel Supply Chain. J. Bus. Ethics 2019, 159, 1047-1064. [CrossRef]

57. Fontoura, P.; Coelho, A. The impact of Supply Chain Leadership and Followership on CSR: An empirical study about a Portuguese energy supplier. E + M Èkon. Manag. 2020, 23, 75-92. [CrossRef]

58. Wen, D.; Sun, X.; Liu, Y. Bibliometric Analysis of Supplier Management: The Theme and Cluster Perspectives. Sustainability 2020, 12, 2572. [CrossRef]

59. Hoque, I.; Rana, M.B. Buyer-supplier relationships from the perspective of working environment and organisational performance: Review and research agenda. Manag. Rev. Q. 2019, 70, 1-50. [CrossRef]

60. Yang, T.-K.; Yan, M.-R. The Corporate Shared Value for Sustainable Development: An Ecosystem Perspective. Sustainability 2020, 12, 2348. [CrossRef]

61. Chihambakwe, Z.J.; Grobbelaar, S.S.S.; Matope, S. Creating Shared Value in BoP Communities with Micro-Manufacturing Factories: A Systematized Literature Review. Sustainability 2021, 13, 10289. [CrossRef]

62. Xu, L.; Kumar, D.T.; Shankar, K.M.; Kannan, D.; Chen, G. Analyzing criteria and sub-criteria for the corporate social responsibilitybased supplier selection process using AHP. Int. J. Adv. Manuf. Technol. 2013, 68, 907-916. [CrossRef]

63. Lindgreen, A.; Révész, B.; Glynn, M.; Svahn, S.; Westerlund, M. Purchasing strategies in supply relationships. J. Bus. Ind. Mark. 2009, 24, 173-181. [CrossRef] 
64. Hatipoglu, B.; Ertuna, B.; Salman, D. Corporate social responsibility in tourism as a tool for sustainable development. Int. J. Contemp. Hosp. Manag. 2019, 31, 2358-2375. [CrossRef]

65. Haski-Leventhal, D. Strategic Corporate Social Responsibility: Tools and Theories for Responsible Management; SAGE: New York, NY, USA, 2018.

66. Choy, K.; Lee, W.; Lau, H.C.; Choy, L. A knowledge-based supplier intelligence retrieval system for outsource manufacturing. Knowl.-Based Syst. 2005, 18, 1-17. [CrossRef]

67. Yigitbasioglu, O.M. Information sharing with key suppliers: A transaction cost theory perspective. Int. J. Phys. Distrib. Logist. Manag. 2010, 40, 550-578. [CrossRef]

68. Chae, S.; Yan, T.; Yang, Y. Supplier innovation value from a buyer-supplier structural equivalence view: Evidence from the PACE awards in the automotive industry. J. Oper. Manag. 2019, 66, 820-838. [CrossRef]

69. Lee, C.C.; Yang, J. Knowledge value chain. J. Manag. Dev. 2000, 19, 783-793.

70. Tranfield, D.; Denyer, D.; Smart, P. Towards a Methodology for Developing Evidence-Informed Management Knowledge by Means of Systematic Review. Br. J. Manag. 2003, 14, 207-222. [CrossRef]

71. Patel, A.B.; Aran, H. Outsourcing Success: The Management Imperative; Springer: Cham, Switzerland, 2005.

72. Wilhelm, M.; Sydow, J. Managing coopetition in supplier networks-A paradox perspective. J. Supply Chain Manag. 2018, 54, 22-41. [CrossRef]

73. Çelen, A. Comparative Analysis of Normalization Procedures in TOPSIS Method: With an Application to Turkish Deposit Banking Market. Informatica 2014, 25, 185-208. [CrossRef]

74. Bahadori-Chinibelagh, S.; Fathollahi-Fard, A.M.; Hajiaghaei-Keshteli, M. Two Constructive Algorithms to Address a Multi-Depot Home Healthcare Routing Problem. IETE J. Res. 2019, 1-7. [CrossRef]

75. Amiri, S.A.S.H.; Zahedi, A.; Kazemi, M.; Soroor, J.; Hajiaghaei-Keshteli, M. Determination of the optimal sales level of perishable goods in a two-echelon supply chain network. Comput. Ind. Eng. 2020, 139, 106156. [CrossRef]

76. Karampour, M.M.; Hajiaghaei-Keshteli, M.; Fathollahi-Fard, A.M.; Tian, G. Metaheuristics for a bi-objective green vendor managed inventory problem in a two-echelon supply chain network. Sci. Iran. 2020. [CrossRef]

77. Ruggeri, G.; Orsi, L.; Corsi, S. A bibliometric analysis of the scientific literature on Fairtrade labelling. Int. J. Consum. Stud. 2019, 43, 134-152. [CrossRef]

78. Meemken, E.-M.; Sellare, J.; Kouame, C.N.; Qaim, M. Effects of Fairtrade on the livelihoods of poor rural workers. Nat. Sustain. 2019, 2, 635-642. [CrossRef] 